\title{
Taxonomy and palaeoecology of a decapod crustacean assemblage from the Oxfordian of Stránská skála (Southern Moravia, Czech Republic)
}

\author{
MATÚŠ HYŽNÝ, NATALIA STARZYK, CRISTINA M. ROBINS \& MARTINA KOČOVÁ VESELSKÁ
}

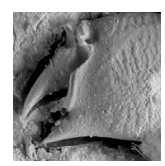

\begin{abstract}
Primitive brachyurans and other decapods have been extensively reported from deposits of Oxfordian age, often termed microbial-sponge and coral megafacies distributed across the entirety of Europe. During the Oxfordian, coral reefs were far less common than microbial-sponge build-ups. The occurrences of decapods associated with such coral facies include those in France, Romania and the Czech Republic. Regarding the Czech Republic, the assemblage from the Stránská skála Hill has been evaluated; it is composed of at least six species including Gastrosacus wetzleri, Eomunidopsis cf. E. neojurensis, Longodromites angustus, Goniodromites narinosus, Goniodromites serratus and Eodromites grandis. Besides the dorsal carapace material, isolated chelae are described as well. As they are not preserved in direct association with taxonomically significant carapaces, they are treated in open nomenclature. Differential diversity of decapods at Stránská skála is relatively low compared to slightly younger Tithonian coral- associated assemblages from Romania. Out of 36 studied specimens, three bear a swelling on the branchial region interpreted to be a result of an isopod infestation. The relatively high percentage of infestation (8.33\%) can be explained by collection bias since carapaces with bopyriform swellings can be considered more attractive to collectors. - Key words: Oxfordian, Czech Republic, Decapoda, differential diversity, bopyrid infestation.
\end{abstract}

HYŽNÝ, M., STARZYK, N., RobinS, C.M. \& KoČOVÁ VeSELSKÁ, M. 2015. Taxonomy and palaeoecology of a decapod crustacean assemblage from the Oxfordian of Stránská skála (Southern Moravia, Czech Republic). Bulletin of Geosciences 90(3), 633-650 (8 figures, 3 tables). Czech Geological Survey, Prague. ISSN 1214-1119. Manuscript received February 25, 2015; accepted in revised form July 2, 2015; published online September 8, 2015; issued September 30, 2015.

\begin{abstract}
Matúš Hyžný, Natural History Museum, Vienna, Burgring 7, AT-1010 Vienna, Austria; Department of Geology and Palaeontology, Faculty of Natural Sciences, Comenius University, Ilkovičova 6, SK-842 15 Bratislava, Slovakia; matus.hyzny@nhm-wien.ac.at, hyzny.matus@gmail.com•Natalia Starzyk, Institute of Systematics and Evolution of Animals, Polish Academy of Sciences, ul. Stawkowska 17, 31-016 Kraków, Poland; natalia_slaby@wp.pl•Cristina M. Robins, Florida Museum of Natural History, University of Florida, 1659 Museum Road, PO Box 117800, Gainesville, FL, 32611 USA; cristina.robins@gmail.com•Martina Kočová Veselská, Institute of Geology and Palaeontology, Faculty of Science, Charles University, Albertov 6, CZ-128 43 Prague, Czech Republic; veselskamartina@gmail.com
\end{abstract}

Decapod crustaceans of the European Upper Jurassic reefal facies have recently received quite a bit of attention. This is especially true of the primitive brachyurans that have been extensively reported from the Oxfordian microbial-sponge and coral megafacies distributed across the entirety of Europe (e.g. Wehner 1988, Müller et al. 2000, Feldmann et al. 2006, Schweitzer et al. 2007a, b, Krobicki \& Zatoń 2008, Franțescu 2011). During the Oxfordian, coral reefs were far less common than microbial-sponge build-ups. Coral reefs were dispersed across the carbonate platforms of the northern margin of the Tethys (Wierzbowski 2004, Krobicki \& Zatoń 2008, Hyžný et al. 2011). The occurrences of decapods associated with such coral facies are known from the northern Paris Basin (Bertling \& Insalaco 1998), Central Dobrogea of Romania (Schweitzer et al. 2007b, Franțescu 2011) and Stránská skála Hill near Brno in the
Moravian part of the Czech Republic (Oppenheimer 1926, Jaroš \& Zapletal 1928).

With regard to decapod crustaceans, Stránská skála Hill has received only minor attention. In fact, since the work of Oppenheimer (1926), no evaluation of the decapod assemblage has been done, partly because the locality has been protected by law since 1978. In 1992 it became a national reserve; thus, no collecting at the locality is possible now.

From Stránská skála, Oppenheimer (1926) mentioned two primitive "crabs": Prosopon aculeatum Quenstedt, 1858 (= Gastrosacus wetzleri von Meyer, 1851) and Pithonoton rostratum (von Meyer, 1840). He figured only the former taxon (Oppenheimer 1926, pl. 1, fig. 1). The latter species is currently classified within the genus Eodromites Patrulius, 1959; thus, it is possible that Oppenheimer (1926) reported on the occurrence of Eodromites grandis (von Meyer, 1857) as 


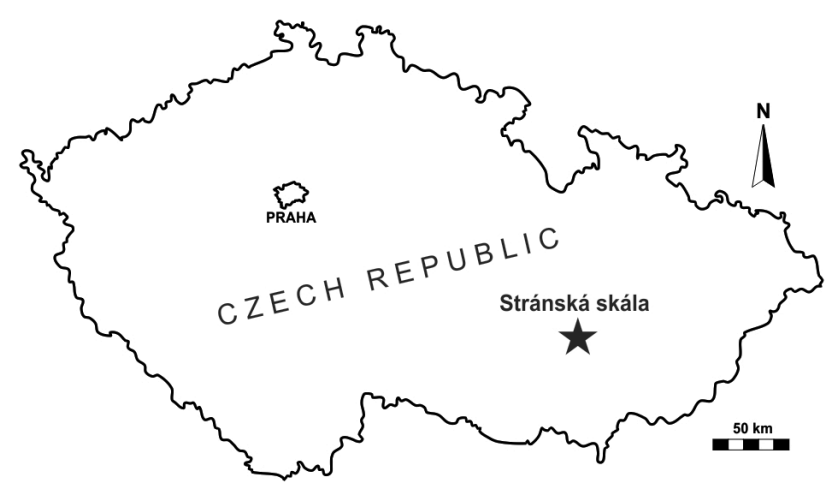

Figure 1. Location of Stránská skála.

recognized herein. Later, Eliáš (1981) confirmed the presence of decapods at the locality, but with no identification at family (or lower) level.

The re-examination of older collections allows for a systematic description of the assemblage, which is one of the goals of the present study. The other goal is the evaluation of the assemblage in terms of differential diversity of coeval decapod assemblages.

\section{Geological settings}

The studied material comes from the Upper Jurassic rocks exposed at Stránská skála Hill in the eastern part of Brno (Brunn), Czech Republic (Fig. 1). Stránská skála is located in the borough Brno-Slatina (co-ordinates $49^{\circ} 11,458^{\prime} \mathrm{N}$, $\left.16^{\circ} 40,699^{\prime} \mathrm{E}\right)$. It is a natural elevation $(310 \mathrm{~m}$ above sea level), about $1.5 \mathrm{~km}$ long and $0.5 \mathrm{~km}$ wide, and is one of the few localities in the Brno area where Jurassic sediments are exposed. In the past, several quarries operated here.

Geological studies of this area have a long history, starting in the $19^{\text {th }}$ century with the work of Uhlig (1881), who described various rocks and fossils from the Stránská skála. Later, Oppenheimer (1926) provided an overview of the macrofauna. The geological settings and sedimentological conditions were described by Eliáš $(1969,1981)$, Eliáš \& Eliášová (1984) and Adámek (2005). The palaeogeographic settings were outlined by Adámek (2005).

Jurassic deposits lie transgressively upon Upper Devonian and Lower Carboniferous rocks at Stránská skála Hill. The thickness of the Upper Jurassic limestone strata is approximately $50 \mathrm{~m}$. The Upper Jurassic sequence exposed at Stránská skála can be divided into three parts (Oppenheimer 1926, Koutek 1926, Eliáš 1981): 1) the lower part is composed of massive, grey, cherty limestone with grey, finely-laminated limestone and pseudo-oolithic limestone with radiolarian and echinoderm remains in the uppermost portion of the layer; 2) the middle part consists of a 3-4 m thick sequence of white-grey, coarse, detritic, crinoidal limestone containing $80-90 \%$ of crinoid seg-
Table 1. Synopsis of studied material from the Oxfordian of Stránská skála.

\begin{tabular}{lr}
\hline Taxon & Number of specimens \\
\hline Squat lobsters (Galatheoidea) & 3 \\
Gastrosacus wetzleri von Meyer, 1854 & 2 \\
Eomunidopsis cf. Eomunidopsis neojurensis (Patrulius, 1959) & \\
Brachyuran crabs (Brachyura) & 3 \\
Longodromites angustus (Reuss, 1858) & 3 \\
Goniodromites narinosus Franțescu 2011 & 12 \\
Goniodromites serratus Beurlen, 1929 & 1 \\
Eodromites grandis (von Meyer, 1857) & 7 \\
Goniodromitidae indet. & 5 \\
Indeterminate chela sp. 1 & 36
\end{tabular}

ments, previously mentioned by Uhlig (1881); 3) the uppermost part represents an approximately $8 \mathrm{~m}$ thick well-bedded sequence consisting of fragments of coarse, bioclastic and pseudo-oolithic limestone with abundant remains of echinoderms, algae, bryozoans and other organisms including decapod crustaceans. The entire sequence is silicified with quartz and chalcedony.

According to Vašíček (1973), the lower part of the section at the Stránská skála Hill represents the Middle Oxfordian (Plicatilis ammonite Biozone sensu Cariou et al. 1997), whereas the upper parts extend to the Upper Oxfordian (Transversarium and Bimammatum ammonite biozones sensu Cariou et al. 1997).

\section{Material and methods}

The material consists of isolated carapaces or chelae typically preserved as internal moulds (Feldmann et al. 2006). All specimens are dissociated; i.e. no chela has been found directly associated with a dorsal carapace. Altogether 36 specimens were examined (Table 1).

For comparative reasons, material from different localities was studied as well; specifically, type specimens and additional specimens, mainly from Štramberk (Czech Republic) and Ernstbrunn (Austria), were studied. Details are given in the Systematic palaeontology chapter.

Terminology for the galatheoid descriptions follows Robins et al. (2013). Terminology for brachyuran descriptions follows Schweitzer \& Feldmann (2009) and Starzyk et al. (2012) except usage of the term "augenrest". We prefer to use the term "false orbit" as used and depicted by Wright \& Collins (1972, p. 44, text-fig. 8). The same structure is called "plage orbitaire" by Guinot \& Richer de Forges (1995). Because the state of cuticle preservation may alter the appearance of some taxonomically important characters (Feldmann \& Portell 2007, Waugh et al. 2009, 
Fraaije et al. 2013a, Klompmaker et al. 2015) information on the presence or absence of cuticle is supplied for every studied specimen.

Synonymies are kept as brief as possible and include only works that markedly contributed to the knowledge of the respective taxon.

All measurements are in millimetres.

The fossils were studied using stereomicroscope Leica EZ4. They were photographed either dry or coated with ammonium chloride. Photographs were made with an Olympus SP-510UZ camera and Nikon Coolpix P7800.

Repositories: Bayerische Staatssammlung für Paläontologie und historische Geologie München, Germany (BSP); Chlupáčovo Muzeum historie Země, Charles University, Prague, Czech Republic (CHMHZ); Geologisches Bundesanstalt, Vienna, Austria (GBA); Naturhistorisches Museum Wien, Austria (NHMW); Slovenské národné múzeum - Prírodovedné múzeum, Bratislava, Slovakia (SNM-Z); Ústav geologických věd, Masarykova univerzita, Brno, Czech Republic (IGS-MJ).

\section{Systematic palaeontology}

Order Decapoda Latreille, 1802

Suborder Pleocyemata Burkenroad, 1963

Infraorder Anomura MacLeay, 1838

Superfamily Galatheoidea Samouelle, 1819

Family Munidopsidae Ortmann, 1898

\section{Genus Gastrosacus von Meyer, 1851}

Type species. - Gastrosacus wetzleri von Meyer, 1851, by monotypy.

Species included. - G. aequabus Robins, Feldmann \& Schweitzer, 2013; G. eminens (Blaschke, 1911); G. ernstbrunnensis Bachmayer, 1947; G.? latirostris Beurlen, 1929; G. levocardiacus Robins, Feldmann \& Schweitzer, 2013; G. limacurvus Robins, Feldmann \& Schweitzer, 2013; G. meyeri (Moericke, 1889); G. pisinnus Robins, Feldmann \& Schweitzer, 2013; G. torosus Robins, Feldmann \& Schweitzer, 2013; G. tuberosiformis (Lôrenthey in Lőrenthey \& Beurlen, 1929); G. tuberosus (Remeš, 1895); G. ubaghsi (Pelseneer, 1886); G. wetzleri von Meyer, 1851.

Diagnosis. - See Robins et al. (2013, p. 181).

Remarks.-Gastrosacus von Meyer, 1851 is the most speciose fossil munidopsid genus, found in strata ranging from the Upper Jurassic to Upper Cretaceous; geographically, the range of Gastrosacus extends from England to Romania (Robins et al. 2013, table 9). Recently, Ro- bins et al. (2013) provided discussion on the taxonomy of the genus.

Gastrosacus wetzleri von Meyer, 1851

Figures 2A-C, 8A

1854 Gastrosacus Wetzleri von Meyer, p. 51, pl. 10, figs $3,4$.

1858 Prosopon aculeatum Quenstedt, p. 779, pl. 95, figs 46, 47.

1860 Gastrosacus Wetzleri von Meyer. - von Meyer, p. 219 , pl. 23, fig. 34 .

1926 Prosopon aculeatum Quenstedt. - Oppenheimer, p. 151 , pl. 1, fig. 1 .

?1963 Gastroracus (sic) n. sp. - Houša, table 3.

2013 Gastrosacus carteri Van Straelen. - Robins et al., p. 184, figs 7.9.

2013 Gastrosacus wetzleri von Meyer. - Robins et al., p. 181, figs $6.11,7.1$.

2015 Gastrosacus wetzleri von Meyer. - Robins et al., pp. 87-89, figs 2A-O, 3A-K, 4.

(abbreviated synonymy)

Material. - Fragmentary specimens CHMHZ-DSS/0001 (max. carapace width $=7.4$; length of gastric region $=4.6$ ); SNM-Z 10299 ( $\max$. preserved carapace width $=4.3$; length of gastric region $=3.8$ ) and IGS-MJ-0040 (left posterolateral portion of the carapace). All specimens are preserved without any cuticular surfaces intact.

Diagnosis. - See Robins et al. (2015).

Description. - Carapace incomplete; lateral and posterior margins absent. Carapace longer than wide; rostrum axially keeled, narrowly triangular. Circumgastric groove well defined. Epigastric, protogastric, mesogastric, and metagastric regions well defined; each individual region bordered anteriorly by larger pustules. Cardiac region well defined; sub-pentagonal in shape, apex directed posteriorly. Ornamentation consists of larger pustules and smaller tubercles; pustules clustered at anterior of defined regions.

Remarks. - The description above was based on the specimen SNM-Z 10299 and CHMHZ-DSS/0001. Another more fragmentary specimen, consisting of the lower left quadrant of the carapace (IGS-MJ-0040), is also attributed to Gastrosacus wetzleri based on the overall similarities of the ornamentation and groove structure with SNM-Z 10299 and the neotype of G. wetzleri (Robins et al. 2013, fig. 7.1; Robins et al. 2015, fig. 2C).

Houša (1963), in his review of parasitized Tithonian decapods of the Czech Republic, listed Gastroracus (sic) n. sp. as a host of Bopyridae from Stránská skála near Brno. 
It is possible that this occurrence actually represents Gastrosacus wetzleri, but as no figure was supplied by Houša (1963), and he did not report on this new species in his subsequent publications, it is difficult to judge the veracity of his new species.

Occurrence. - Upper Jurassic of Germany (localities Oerlinger Tal and Nieder-Stotzingen; see Quenstedt 1858 and von Meyer 1854, 1860); Czech Republic (Stránská skála; Oppenheimer 1926, herein); England (Upper Coral Rag at Upware; see Carter 1898 and Robins et al. 2015). The occurrences from Stramberk (Czech Republic), Ernstbrunn (Austria), and Romanian localities were not able to be verified by Robins et al. (2013) and probably represent Cracensigillatus acutirostris (Moericke, 1889).

Family Galatheidae Samouelle, 1819

\section{Genus Eomunidopsis Vía Boada, 1981}

Type species. - Galathea orobensis Ruiz de Gaona, 1943, by original designation.

Species included. - Eomunidopsis aldoirarensis Klompmaker, Feldmann, Robins \& Schweitzer, 2012; E. eutecta (Moericke, 1889); E. kinokunica Karasawa, Ohara \& Kato, 2008; E. meerssensis Collins, Fraaye \& Jagt, 1995; E. neojurensis (Patrulius, 1959) (= Galathea antiqua Moericke, 1889); E. navarrensis (Van Straelen, 1940); E. orobensis (Ruiz de Gaona, 1943); E. portlandica Fraaye \& Collins, 1996.

Diagnosis. - Cephalothorax elongated, bearing protruding transverse ridges. Regions bounded by visible grooves. Rostrum characterized by tridentate tip, devoid of serration on its lateral edges and bearing a median keel. [Translated from Vía Boada (1982).]

Remarks. - Eomunidopsis Vía Boada, 1981, ranges from the Oxfordian to Maastrichtian, and has been found at many localities in Europe, Japan, and the United States (Vía Boada 1982, Collins et al. 1995, Fraaye \& Collins 1996, Karasawa et al. 2008, Klompmaker et al. 2012a). The diagnosis allows for a wide variety of morphologies to be accommodated within the genus. Eomunidopsis is currently being revised by one of us (CMR).

\section{Eomunidopsis sp. cf. Eomunidopsis neojurensis}

(Patrulius, 1959) (= Galathea antiqua Moericke, 1889; nomen preoccupatum Galathea antiqua Risso, 1815) Figures 2D-F

1889 Galathea antiqua Moericke, p. 54, pl. 6, fig. 4.
1959 Galathea neojurensis Patrulius, pp. 250-252, fig. 2c.

1982 Eomunidopsis neojurensis (Patrulius). - Vía Boada, p. 122.

(abbreviated synonymy)

Material. - Fragmentary carapaces without cuticle IGS-MJ-0053 (max. preserved carapace width = 10.7; width of gastric region $=8.3$ ) and CHMHZ-DSS/0002.

Description. - Specimens incomplete; posteriormost part of branchial regions absent. Carapace appears longer than wide; rostrum covers approximately half of the anterior margin. Rostrum incomplete, axially keeled,lateral margin appears straight; rostrum ornamented with weak tubercles. Rostral keel extends onto carapace. Cervical groove well defined, arcs across carapace in broad $\mathrm{U}$ shape; groove weakens slightly approaching lateral margin separating hepatic and epibranchial regions. Gastric region slightly inflated above rostrum and hepatic regions. Epigastric regions well defined by rostral keel axially, weak indentation posteriorly. Mesogastric and cardiac regions weakly defined. Ornamentation across carapace consists of uniformly spaced squamous tubercles. Tubercles appear slightly elongated across cardiac region.

Remarks. - These specimens bear remarkable resemblance to Eomunidopsis neojurensis (Patrulius, 1959; = Galathea antiqua Moericke, 1889) from the Tithonian Štramberk Limestones of the Czech Republic (Blaschke 1911), Poland (Moericke 1889), and Romania (Patrulius 1959). A syntype of E. neojurensis is shown in Fig. 2F (BSP AS III 323). Unfortunately, not enough of the carapace of the Stránská skála specimen is preserved for a definitive assignment.

Occurrence. - Eomunidopsis neojurensis has thus far been found only in strata of Tithonian age of Sinaia, Romania (Patrulius 1959), Radziechów, Poland (Moericke 1889), and Stramberk, Czech Republic (Blaschke 1911); this specimen would extend the range of this species into the Oxfordian.

Infraorder Brachyura Linnaeus, 1758

Section Dromiacea de Haan, 1833

Superfamily Homolodromioidea Alcock, 1900

Family Longodromitidae Schweitzer \& Feldmann, 2009

\section{Genus Longodromites Patrulius, 1959}

Type species. - Prosopon angustum Reuss, 1858, by original designation. 


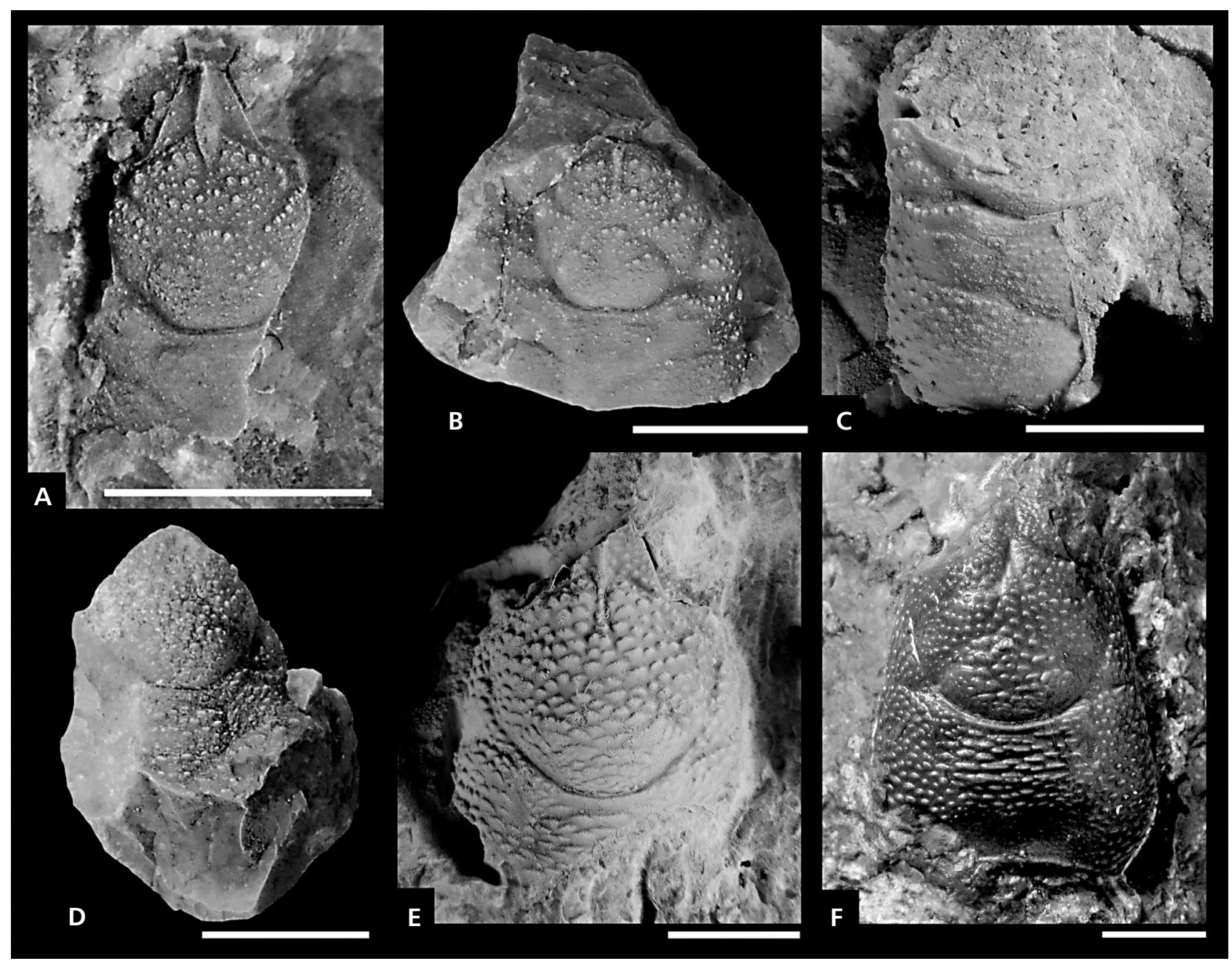

Figure 2. Galatheoid squat lobsters from the Oxfordian of Stránská skála. • A-C - Gastrosacus wetzleri von Meyer, 1854; A - SNM-Z 10299, B - CHMHZ-DSS/0001, C - IGS-MJ-0040. • D, E - Eomunidopsis sp. cf. Eomunidopsis neojurensis (Patrulius, 1959); D - CHMHZ-DSS/0001, E - IGS-MJ-0053. • F - syntype of Eomunidopsis neojurensis, BSP AS III 323. Specimens in A-E were covered with ammonium chloride prior to photography. Scale bar equals $5 \mathrm{~mm}$.

Species included. - L. angustus (Reuss, 1858); L. bicornutus Muțiu \& Bădăluță, 1971; L. excisus (von Meyer, 1857); L. ovalis (Moericke, 1889).

Diagnosis. - See Schweitzer \& Feldmann (2009, p. 101).

Remarks. - The genus is well known from the Upper Jurassic of Central and Eastern Europe. It was recently revised by Schweitzer \& Feldmann (2009).

\section{Longodromites angustus (Reuss, 1858)}

Figures $3 \mathrm{~A}-\mathrm{C}, 8 \mathrm{~B}$

1858 Pithonoton angustum Reuss, p. 11.

1859 Pithonoton angustum Reuss. - Reuss, p. 72, pl. 24, fig. 3.
1895 Prosopon angustum (Reuss). - Remeš, p. 203, pl. 2 , fig. 10.

1959 Longodromites angustus (Reuss). - Patrulius, p. 254, fig. 1a.

1966 Longodromites angustus (Reuss). - Patrulius, p. 514, pl. 31, figs 25, 26.

2009 Longodromites angustus (Reuss). - Schweitzer \& Feldmann, p. 101, figs 1.6, 7.4-7.7.

2011 Longodromites angustus (Reuss). - Franțescu, p. 292, fig. 15.

(abbreviated synonymy)

Material. - Three carapaces without cuticle: CHMHZ-DSS/0005 (well preserved; length excluding rostrum $=8.9$; max. carapace width $=6.9$; width at base of rostrum $=2.5$; fronto-orbital width $=5.6$ ), IGS-MJ-0051 (well preserved; length excluding rostrum $=6.5$; max. carapace 


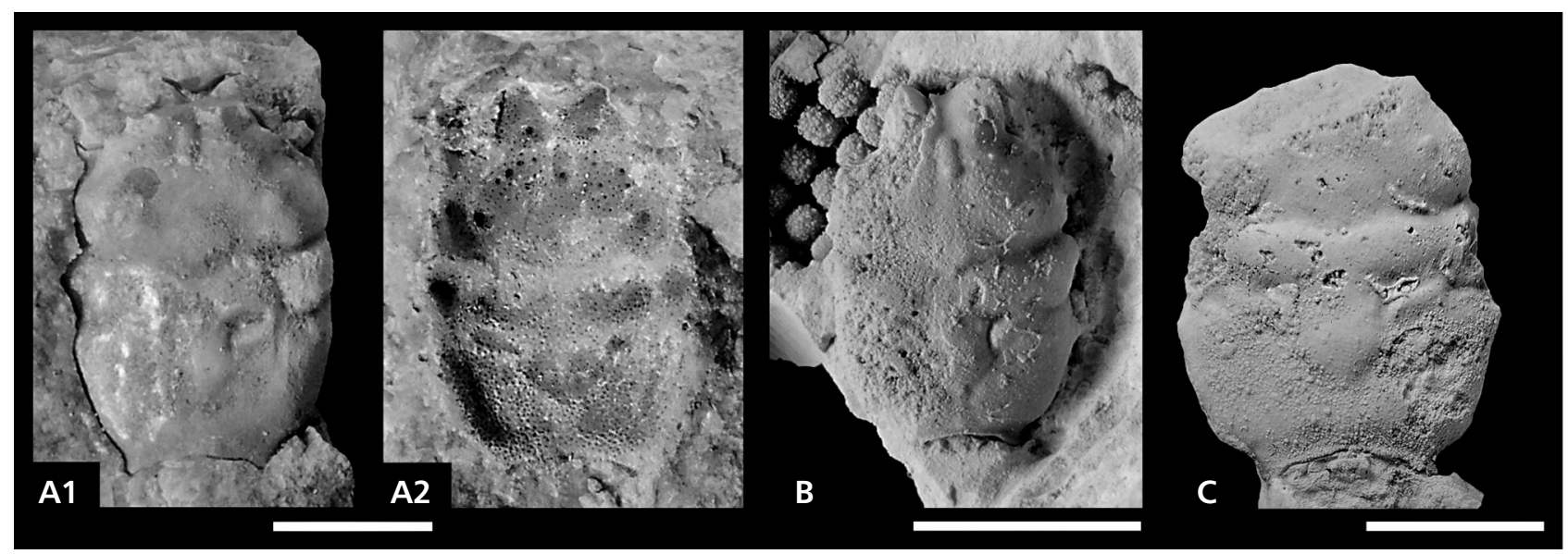

Figure 3. Longodromites angustus (Reuss, 1858) from the Oxfordian of Stránská skála. • A1, A2 - part and counterpart of CHMHZ-DSS/0005, B - IGS-MJ-0051, C - IGS-MJ-0052. All specimens were covered with ammonium chloride prior to photography. Scale bar equals $5 \mathrm{~mm}$.

width $=5.0$; width at base of rostrum $=2.5$; fronto-orbital width $=4.1$ ), IGS-MJ-0052 (without anterior portion; length excluding rostrum $=10.4$; max. carapace width $=8.3$ ).

Comparative material. - Holotype specimen from Štramberk, Czech Republic (GBA 2007/096/0005); note that Schweitzer \& Feldmann (2009) erroneously listed the repository number of the holotype as GSA 2357. Additional specimens from Ernstbrunn, Austria (NHMW 1990/0041/3190) and Štramberk (NHMW 2007/0149/0001).

Diagnosis. - See Schweitzer \& Feldmann (2009, p. 103).

Description. - Carapace longer than wide; width about 0.78 of length without rostrum. Maximum width at epibranchial regions; narrows slightly anteriorly and posteriorly. Anterior part of carapace (anterior to cervical groove) relatively long; more than half carapace length. Epibranchial regions very short, approximately $40 \%$ carapace length (Fig. 3A1). Rostrum broad, long, strongly deflected. Axial groove deep, broad, extends to anterior edge of carapace (Fig. 3B). False orbit deep, posteriorly directed, bounded with intra-orbital spine and outer-orbital spine. Mesogastric and epigastric regions not clearly differentiated. Anterior process of mesogastric region bears single tubercle. Cervical pits present on posterior of mesogastric region. One tubercle present in centre of each hepatic region (Fig. 3). Cardiac region triangular in shape, apex directed posteriorly, with two faint tubercles anteriorly and one, more distinct tubercle posteriorly. Cervical groove very broad and deep. Branchiocardiac groove also broad in lateral parts; the groove shallows and narrows approaching midpoint of carapace; extends to posterior margin of carapace. One large spine located along lateral margin posterior to cervical groove and one posterior to branchiocardiac groove (Fig. 3B, C). Posterior margin of carapace strongly inflected.
Remarks. - The specimens from Stránská skála have two pairs of large spines along the lateral margins; one is behind the cervical groove and one is behind the branchiocardiac groove. Spines on the holotype (GBA 2007/096/0005) and additional specimens from Stramberk and Ernstbrunn (NHMW 2007/0149/0001; NHMW 1990/0041/3190; also published in Schweitzer \& Feldmann 2009, figs 7.4 and 7.6, respectively) are small. The specimens from Stramberk (NHMW 2007/0149/0001) and Ernstbrunn (NHMW 1990/0041/3190) studied for this work have spines of similar size; however, the Štramberk specimen has its cuticle preserved, while the Ernstbrunn specimen is without cuticle. The majority of specimens studied from Stránská skála do not have cuticle preserved. The spines on the Stránská skála specimens are well developed and large, similar to the spines of Romanian specimens, similarly without cuticle, studied by Franțescu (2011, fig. 15). Despite these differences in the size of the spines, which is considered a matter of intraspecific variation, all discussed specimens are close to each other in other morphological aspects.

Occurrence. - This species is known from the Tithonian of Štramberk, Czech Republic and Ernstbrunn, Austria (Schweitzer \& Feldmann 2009), the upper Oxfordian-lower Kimmeridgian of Dobrogea, Romania (Franțescu 2011), and the Oxfordian of Stránská skála (herein).

Family Goniodromitidae Beurlen, 1932

\section{Genus Goniodromites Reuss, 1858}

(= Iberihomola Van Straelen, 1940)

Type species. - Goniodromites bidentatus Reuss, 1858, by original designation. 
Matúš Hyžný et al. • Taxonomy and palaeoecology of a decapod crustacean assemblage from the Oxfordian of Stránská skála

Table 2. Measurements (in mm) of studied brachyuran specimens from the Oxfordian of Stránská skála.

\begin{tabular}{|c|c|c|c|c|c|c|c|c|c|c|c|}
\hline Taxon & specimen & $\mathrm{W}$ & WR & WM & $\mathrm{L}$ & LPM & $\mathrm{MtF}$ & $\mathrm{MtC}$ & $\mathrm{CtE}$ & $\mathrm{CtBc}$ & $\mathrm{BCtE}$ \\
\hline Goniodromites narinosus & IGS-MJ-043 & 12 & 5.3 & 4.4 & - & 3.1 & 7.3 & - & - & - & - \\
\hline G. narinosus & IGS-MJ-049 & 1.0 & - & 3.2 & 10.2 & 2.0 & 5.7 & 2.2 & 2.3 & 2.1 & 4.5 \\
\hline G. narinosus & SNM-Z 10297 (1) & 9.2 & 4.4 & 3.4 & - & 3.0 & - & - & - & 1.7 & - \\
\hline Goniodromites serratus & CHMHZ-DSS/0003 & 9.6 & - & 3.8 & - & 2.1 & - & 2.4 & - & 2.0 & - \\
\hline G. serratus & CHMHZ-DSS/0004 & 4.4 & 2.6 & - & 8.5 & - & - & - & - & 2.1 & 2.7 \\
\hline G. serratus & IGS-MJ-040 & 8.5 & - & 3.3 & - & 2.2 & - & - & - & 1.5 & - \\
\hline G. serratus & IGS-MJ-041 & 7.7 & - & 2.9 & - & 1.5 & - & - & - & 1.3 & - \\
\hline G. serratus & IGS-MJ-042 & 4.1 & 2.4 & 1.4 & 4.6 & 0.6 & 2.5 & 1.1 & 1.0 & 0.6 & 1.0 \\
\hline G. serratus & IGS-MJ-044 & 8.4 & 4.1 & 3.2 & 9.5 & 2.2 & 5.6 & 2.3 & 1.6 & 1.5 & 3.5 \\
\hline G. serratus & IGS-MJ-045 & 8.0 & 4.0 & 2.8 & 9.0 & 1.6 & 5.2 & 2.1 & 1.7 & 1.7 & 4.2 \\
\hline G. serratus & IGS-MJ-046 & 7.4 & 3.5 & 3.1 & 9.0 & 1.7 & 4.6 & 2.2 & 2.2 & 1.5 & - \\
\hline G. serratus & IGS-MJ-050 & 6.7 & - & 2.5 & - & 1.4 & - & 1.8 & 1.4 & 1.2 & 2.5 \\
\hline G. serratus & SNM-Z 10296 & 6.3 & - & 2.3 & 6.4 & 1.6 & - & 1.6 & 1.2 & 1.1 & 2.3 \\
\hline G. serratus & SNM-Z 16019 & 6.6 & 3.5 & 2.5 & $\sim 7.7$ & 2.1 & 4.3 & - & - & 1.4 & 2.6 \\
\hline Eodromites grandis & IGS-MJ-047 & 8.1 & - & 3.6 & - & - & - & - & - & - & - \\
\hline
\end{tabular}

Species included. - Goniodromites aliquantulus Schweitzer, Feldmann \& Lazăr, 2007a; G. bidentatus Reuss, 1858; G. cenomanensis (Wright \& Collins, 1972); G. dentatus Lőrenthey in Lőrenthey \& Beurlen, 1929; G. hirotai Karasawa \& Kato, 2007; G. kubai Starzyk, Krzemińska \& Krzemiński, 2012; G. laevis (Van Straelen, 1940); G. narinosus Franțescu, 2011; G. polyodon Reuss, 1858; G. serratus Beurlen, 1929; G. sakawense Karasawa \& Kato, 2007; G. transylvanicus Lôrenthey in Lörenthey \& Beurlen, 1929.

Diagnosis. - See Schweitzer \& Feldmann (2008, p. 123).

Remarks. - Goniodromites is one of the best known and most widespread, but also has the most convoluted systematic history of the Jurassic homolodromioid crabs. As noted by Schweitzer \& Feldmann (2008) the concept of the genus has expanded significantly since Reuss (1858). Detailed discussion on its taxonomy and occurrence has been presented by Schweitzer \& Feldmann (2008).

\section{Goniodromites narinosus Franțescu, 2011} Figures 4E, H, 8C

2011 Goniodromites narinosus Franțescu, p. 280, fig. 8.

2012 Goniodromites narinosus Franțescu. - Starzyk et al., pp. 147-148, figs 2,6 , 9b.

Material. - Partially incomplete carapaces without cuticle IGS-MJ-0043, IGS-MJ-0049 and SNM-Z 10297 (1). For measurements see Table 2.

Diagnosis. - See Starzyk et al. (2012, p. 147).
Description. - Rostrum broad and very short. Anterior margin of rostrum medially incised at anterior groove, where posterior margin of the rostrum and upper orbital margin meet (Fig. 4H). False orbit long; approximately $20 \%$ of frontal margin length. Upper and lower margins of false orbit finely serrated (preserved on specimen IGS-MJ-0049; Fig. 4E). Epigastric regions swollen, rounded and closely positioned anterior to mesogastric region. Mesogastric region clearly defined anteriorly by hepatic grooves and posteriorly by the cervical groove; pyriform in shape with anterior (narrow) and posterior (broad) parts approximately equivalent in length. Midpoint of posterior part of mesogastric region bears small incision directed axially with pair of cervical pits on each side (Fig. 4E). Cardiac region triangular in shape with apex directed posteriorly, faintly visible. Single spine on posterior part of cardiac region and two nodes on anterior part. Lateral margins possess two spines anterior to cervical groove, four spines between cervical and branchiocardiac grooves and two spines posterior to branchiocardiac groove (Fig. 4E). Posterior margin of carapace long and distinctly concave posteriorly. Carapace ornamented with granules. Cervical groove strongly concave forward. Branchiocardiac groove weaker than the cervical groove, especially in medial part. Postcervical groove interrupted at midpoint.

Remarks. - Differences between Goniodromites narinosus and its morphologically closest congeners are discussed under remarks of $G$. serratus.

Occurrence. - The species is known from the Oxfordian of Romania (Franțescu 2011), Poland (Starzyk et al. 2012) and Czech Republic (herein). 
Goniodromites serratus Beurlen, 1929

Figures 4A-D, G, F, I, 8D

1929 Goniodromites serratus Beurlen, p. 130, fig. 4.

1985 Pithonoton serratum (Beurlen). - Collins \& Wierzbowski, p. 84, pl. 3, figs 2-4, pl. 4, figs 1, 2.

2008 Goniodromites serratus Beurlen. - Schweitzer \& Feldmann, p. 128, pl. 2, fig. f.

2012 Goniodromites serratus Beurlen. - Starzyk et al., pp. 148-149, figs 3, 7, 9a.

(abbreviated synonymy)

Material. - Carapaces CHMHZ-DSS/0003-0004, IGS-MJ0040-0042, IGS-MJ-0044-0046, IGS-MJ-0050, SNM-Z 10296, SNM-Z 16017, SNM-Z 16019; specimens CHMHZ-DSS/0003, IGS-MJ-0044 and IGS-MJ-0046 exhibit bopyriform swellings. Specimens IGS-MJ-0041, 0046 and SNM-Z 10296 are preserved with cuticle partly intact. All cuticular surfaces are preserved on IGS-MJ0044; all other specimens are preserved as internal moulds. The carapace width ranges from 4.1 to $8.5 \mathrm{~mm}$ (Fig. 5), length from 4.6 to $9.5 \mathrm{~mm}$. For measurements see Table 2 .

Diagnosis. - See Starzyk et al. (2012, p. 149).

Description. - Carapace longer than wide, pentagonal, dorsally convex. Rostrum deflected downward, medially incised by groove dividing it into two rounded lobes (Figs 4A1, B2, I2). Upper orbital margin of false orbit finely serrated; serration visible only on best-preserved specimens: IGS-MJ-042 (Fig. 4C), IGS-MJ-046 (Fig. 4A), IGS-MJ-050, and SNM-Z 16019 (Fig. 4I). In lateral view, false orbit comparatively narrow, approximately 1.45 times longer than wide, with upper and lower margins parallel to each other (Fig. 4I2). Epigastric regions swollen and slightly elongated anteriorly. Mesogastric region pyriform, with anterior (narrow) part longer than posterior (broad) part. Anterior-most portion protrudes anteriorly between epigastric regions. Axial incision visible in middle of posterior border. Cardiac region weakly delimited; triangular in shape, apex directed posteriorly. Single spine on posterior angle of cardiac region and two nodes located in both anterior angles. Posterior border of carapace wide and convex-forward. Center of cervical groove marked with pair of pores. Postcervical groove medially interrupted. Branchiocardiac groove deep laterally; groove shallows approaching mid-point, almost disappears in posteriormost part.
Remarks. - The arrangement of spines on the lateral border, i.e. 2 spines in front of the cervical groove, 4 spines between the cervical and branchiocardiac grooves and 2 spines posterior to the branchiocardiac groove (Figs 4D, I1), is characteristic for Goniodromites kubai, $G$. narinosus, and $G$. serratus. The differences are in the proportions of the whole dorsal carapace and the development of particular carapace regions. Goniodromites kubai and $G$. serratus are proportionally longer than $G$. narinosus. Rostra of G. narinosus and G. serratus are incised in the middle, while the anterior outline of $G$. kubai is rounded without any incision. Differences are also visible in the shape and position of the epigastric regions. In G. narinosus the epigastric regions are rounded and close to each other, whereas in. G. serratus, the epigastric regions are slightly elongated and partially separated by the anterior part of the mesogastric region. In G. kubai, the epigastric regions are distinctly elongated and positioned more laterally with respect to the mesogastric region. The false orbits are proportionally the longest in $G$. narinosus (L/W = ca 1.9) and shortest in $G$. kubai $(\mathrm{L} / \mathrm{W}=c a 1.1)$; in $G$. serratus they attain ratio of 1.3.

The dimensions of representatives of Goniodromites serratus and $G$. narinosus from different localities were consistent with one another. The width range of all measured specimens is 3.7-12.8 mm. Specimens from Stránská skála are in the middle of the size range. Their width ranges from 6.3 to $8.5 \mathrm{~mm}$. Specimen IGS-MJ-0042, one of the smallest of all analyzed specimens, is a bit of an outlier - it is $1.4 \mathrm{~mm}$ wide (Fig. 5). The morphometrics of Goniodromites narinosus, although distinguished morphologically from its congeners by Franțescu (2011) and Starzyk et al. (2012), show strong overlap with $G$. serratus (Starzyk et al. 2012, fig. 10; Figs 5, 8C, D herein). Interestingly, at Kraków-Częstochowa Upland (Poland) and Stránská skála, the specimens of $G$. narinosus are almost always larger than G. serratus, and all specimens of both species appear to represent a single assemblage from each locality (Fig. 5). In other words, no specimen of $G$. narinosus with carapace width less than $5 \mathrm{~mm}$ is known. Assuming that both species had larvae of comparable size, juvenile specimens with carapace widths of several millimetres should be present at the studied localities, similar to the goniodromitids at the Koskobilo quarry in Spain (Klompmaker et al. 2012b). The expression of taxonomically important characters on the species level may be linked to some environmental factor,

Figure 4. Goniodromitid crabs from the Oxfordian of Stránská skála, Goniodromites serratus Beurlen, 1929 (A-D, F, G, I) and G. narinosus Franțescu, 2011 (E, H). • A - IGS-MJ-0046 in dorsal (A1) and lateral view (A2). • B - IGS-MJ-044 in lateral (B1), dorsal (B2) and frontal view (B3). - C - IGS-MJ-0042. • D - IGS-MJ-0041. • E - IGS-MJ-0049. • F - IGS-MJ-0045. • G - CHMHZ-DSS/0003 in dorsal (G1) and lateral view (G2). - H - IGS-MJ-0043. - I - SNM-Z 16019 in dorsal (I1) and dorsolateral view (I2). Specimens depicted in A, B and G bear swellings (arrows). All specimens were covered with ammonium chloride prior to photography. Scale bar equals $5 \mathrm{~mm}$. 


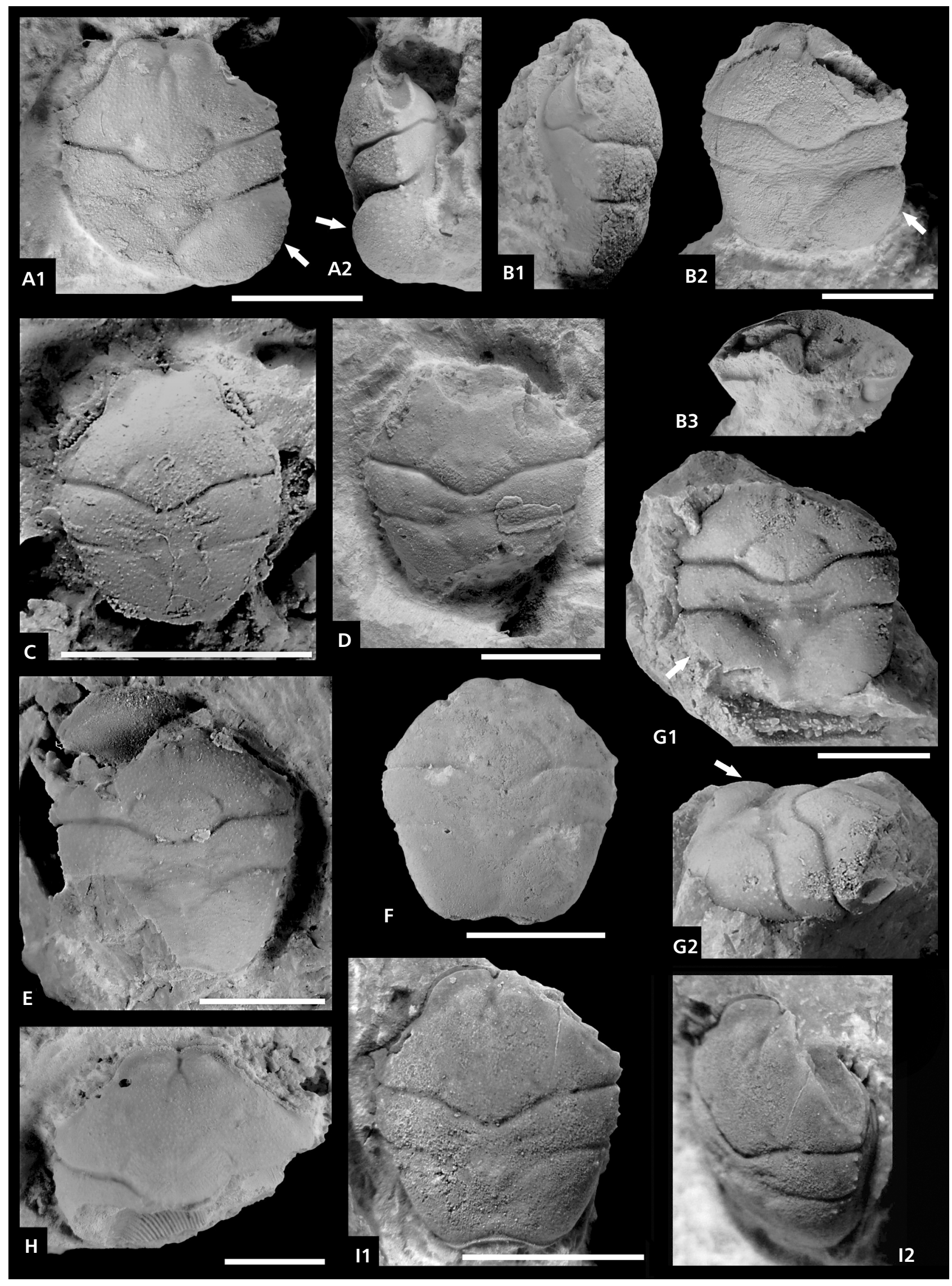




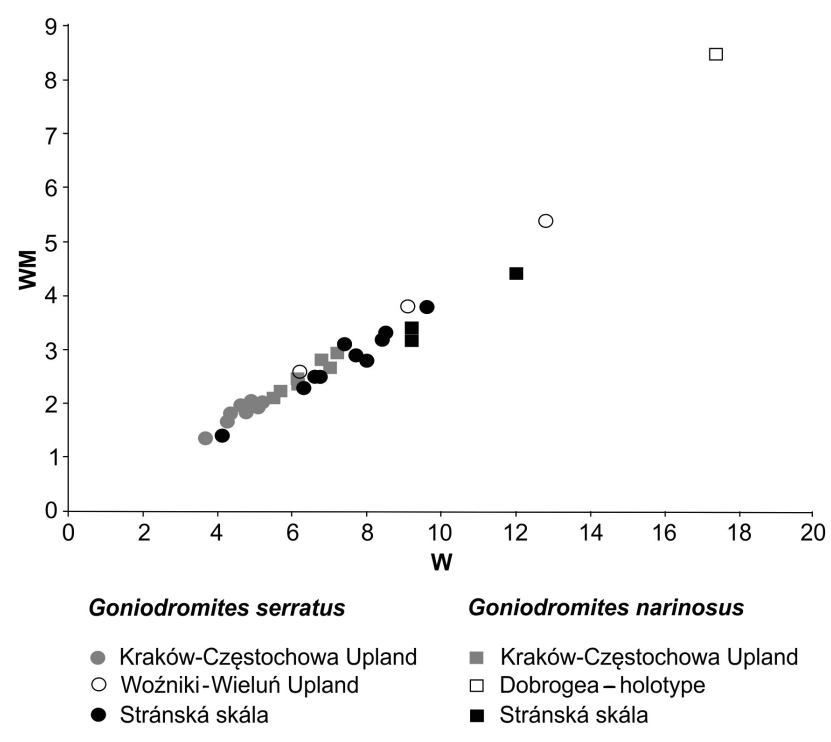

Figure 5. Goniodromites narinosus Franțescu, 2011 and G. serratus Beurlen, 1929. Variation in the carapace width (W) and mesogastric region width (WM) in different localities. Values are in millimetres.

which could explain the size differences of $G$. serratus and G. narinosus at respective localities (Fig. 5). Collecting bias may be another explanation; at least in the case of Stránská skála, only a limited number of specimens were gathered for the study herein. Additionally, at the type locality of $G$. narinosus in Romania, no specimen of G. serratus was recorded (Franțescu 2011). Differences between $G$. narinosus and G. serratus deserve more attention in future studies.

Occurrence.-Goniodromites serratus is one of the most common brachyurans at European Oxfordian localities. It is known from France, Germany, Poland, Romania, Switzerland and the Czech Republic (Beurlen 1929, Collins \& Wierzbowski 1985, Wehner 1988, Feldmann et al. 2006, Starzyk et al. 2012).

\section{Genus Eodromites Patrulius, 1959}

(= pars Prosopon von Meyer, 1835;

Ogydromites A. Milne-Edwards, 1865)

Type species. - Prosopon grande von Meyer, 1857, by original designation.

Species included. - Eodromites aequilatus (von Meyer, 1857); E. depressus (von Meyer, 1860); E. dobrogea (Feldmann, Lazar \& Schweitzer, 2006); E. grandis (von Meyer, 1857); E. nitidus (A. Milne-Edwards, 1865); E. polyphemi (Gemmellaro, 1869); E. rostratus (von Meyer, 1840).

Diagnosis. - See Klompmaker et al. (2012b, p. 790).
Remarks. - The genus was revised by Schweitzer \& Feldmann (2008) and Klompmaker et al. (2012b). For details on the taxonomy and occurrences see those works.

\section{Eodromites grandis (von Meyer, 1857) \\ Figures 6A-C, 8E}

1857 Prosopon grande von Meyer, p. 556.

1857 Prosopon grande von Meyer. - Quenstedt, pl. 95, figs 41, 43, 44.

1860 Prosopon grande von Meyer. - von Meyer, p. 202, pl. 23, figs 1-3.

1895 Prosopon grande von Meyer. - Remeš, p. 203, pl. 2, fig. 12.

1966 Eodromites grandis (von Meyer). - Patrulius, p. 509, pl. 30, figs 10-14.

2008 Eodromites grandis (von Meyer). - Schweitzer \& Feldmann, p. 134, pl. 4, figs a-g.

2011 Eodromites grandis (von Meyer). - Franțescu, p. 283 , fig. 9.

2012 Eodromites grandis (von Meyer). - Klompmaker et al., p. 790, figs 5a-k.

(abbreviated synonymy)

Diagnosis. - "Subovoid carapace varying from longer than wide to as long as wide, widest just posterior to intersection of cervical groove with lateral margin. Rostrum triangular, downturned. Orbits elongate. Orbital rim with axial indent, and outer orbital projection directed forward. Mesogastric region only defined anteriorly and posteriorly. Cardiac region does not reach posterior margin. Cervical groove generally broadly V-shaped. Branchiocardiac groove only defined laterally. Posterior margin accompanied by groove." Excerpted from Klompmaker et al. (2012b, p. 790).

Material. - Partially incomplete carapace IGS-MJ-0047 without cuticle. For measurements see Table 2.

Description. - Carapace approximately as long as wide, strongly convex transversely, especially anteriorly. Branchial region comparatively flattened. Carapace narrows posteriorly, widest point posterior to intersection of cervical groove and lateral margin (Fig. 6C). Outer-orbital spine sharp and well defined. Distance between outer-orbital spine and cervical groove long. Rostrum not preserved. False orbit long, deep and distinctly bordered. Lower margin protrudes further anteriorly than upper margin (white arrow in Fig. 6C). Epigastric regions not preserved. Mesogastric region pyriform, weakly defined. Small, poorly developed incision at mid-point of posterior part of mesogastric region (Fig. 6C). One group of hepatic pits present in middle of each hepatic region (Fig. 6C). Cardiac region undifferentiated. Posterior border of carapace and branchial 


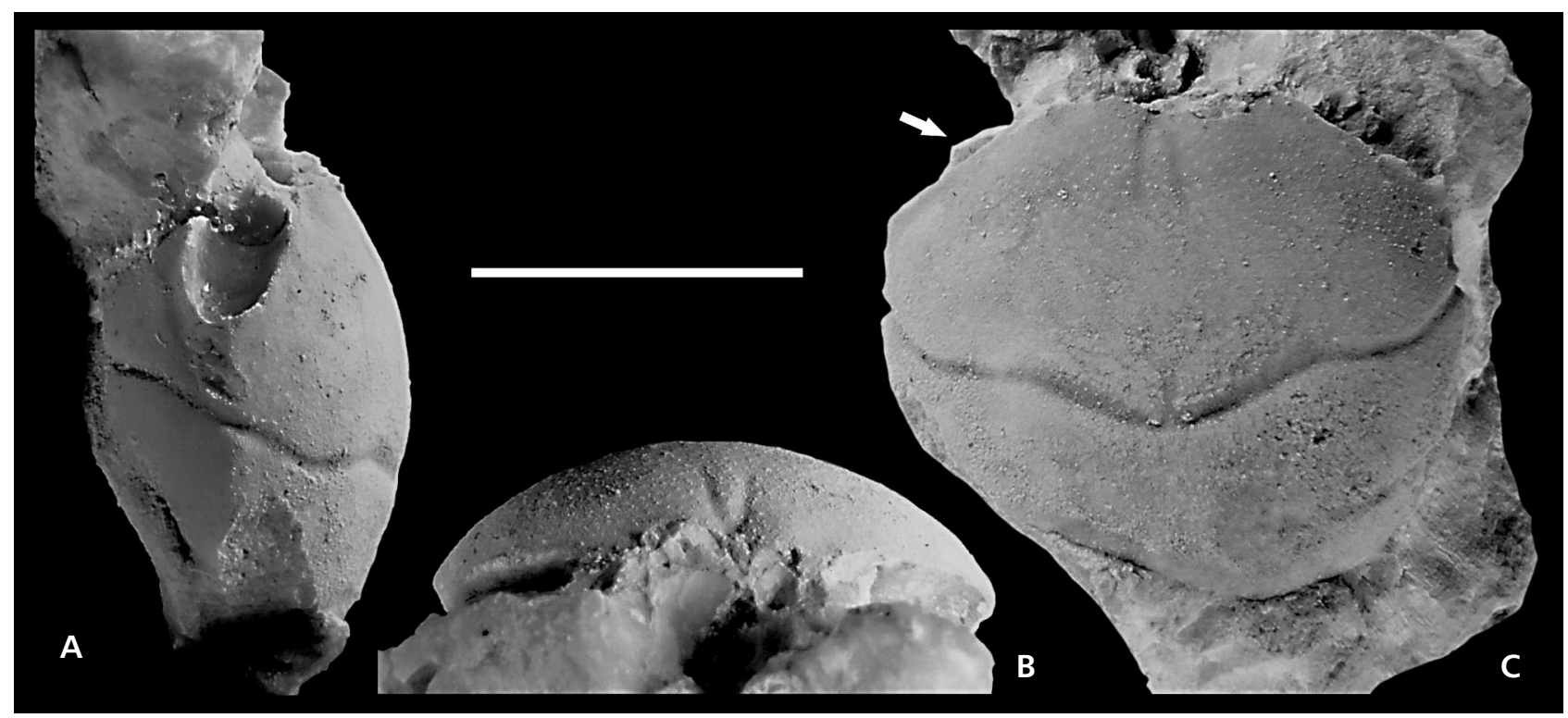

Figure 6. Eodromites grandis (von Meyer, 1857) from the Oxfordian of Stránská skála. Partial dorsal carapace IGS-MJ-0047 in lateral (A), frontal (B) and dorsal view (C). Note the protruded suborbital margin in C (arrow). Specimen was covered with ammonium chloride prior to photography. Scale bar equals $5 \mathrm{~mm}$.

regions not preserved. Carapace surface smooth with shallow grooves. Cervical groove deepest, strongly arched posteriorly. Postcervical groove not visible; branchiocardiac groove faintly visible.

Occurrence. - Eodromites grandis was reported from the Oxfordian of Portugal (Wehner 1988), the Oxfordian-Tithonian of Germany, Poland and Romania (von Meyer 1860, Patrulius 1966, Wehner 1988, Franțescu 2011), and the Tithonian of Austria and the Czech Republic (Moericke 1889, Remeš 1895, Blaschke 1911, Bachmayer 1947). It has been reported also from the Albian/Cenomanian patch reef of Koskobilo, Spain (Klompmaker et al. 2012b).

Family Goniodromitidae Beurlen, 1932

Gen. et sp. indet.

Material. - Carapace fragments without cuticle CHMHZ-DSS/0007-0010, IGS-MJ-048, SNM-Z 13893, and SNM-Z 13895.

Remarks. - The preserved carapace fragments (no margins preserved) indicate affinities to Goniodromitidae. Closer identification, however, is not possible.

\section{Isolated cheliped elements}

Remarks. - The classification of isolated cheliped fragments is difficult, mainly because chelae are prone to con- vergences, and thus offer only a few taxonomically important characters for closer identification. Nevertheless, isolated chelae, namely propodi (sometimes articulated with dactyli), are present at Jurassic localities where dorsal carapaces of primitive brachyurans occur, and they are not scarce (MH, personal communication to Andreas Kroh and Petr Skupien as cited in Hyžný et al. 2011). Only limited attention has been paid to isolated chelae loosely associated with Upper Jurassic primitive brachyurans (von Meyer 1860, Feldmann et al. 2006, Crônier \& Boursicot 2009, Hyžný et al. 2011).

\section{Indeterminate chela sp. 1}

Figures 7A-D

?2006 indeterminate chela sp. 1: Feldmann et al., p. 17, figs 3.7-3.9.

?2011 indeterminate chela sp. 1: Hyžný et al., p. 219, fig. 3 .

Material. - Four right fragmentary chelae consisting of articulated propodi and dactyli (IGS-MJ-042, IGS-MJ-054, IGS-MJ-055 - two chelae in close proximity to each other; Figs 7C, D and A, respectively) and one fragmentary left propodus (IGS-MJ-058; Fig. 7B). Only one of the specimens, IGS-MJ-055, partially retains original cuticle, all other specimens are preserved as internal moulds without any original cuticle.

Description. - Manus of chela longer than high (L/H 1.15 ), convex on lateral surfaces (more convex on outer 


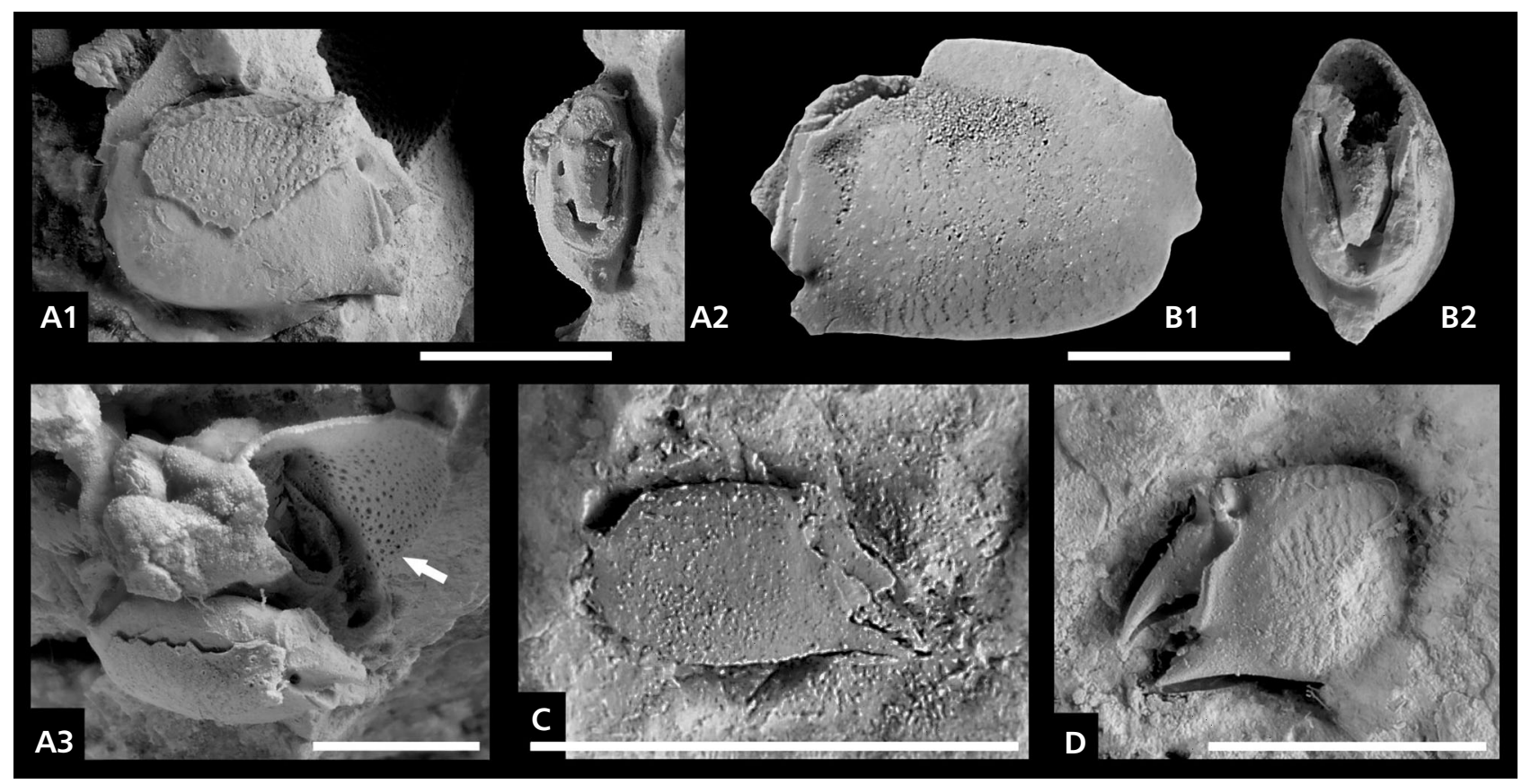

Figure 7. Isolated crab chelae (propodi with articulated dactyli) from the Oxfordian of Stránská skála. • A - right chela IGS-MJ-0055 in lateral (A1) and frontal view (A2). Note the presence of another chela associated with this specimen in A3 (arrow). $\bullet$ B - left chela IGS-MJ-0058 in lateral (B1) and frontal view (B2). • C - right chela IGS-MJ-0042. • D - right chela IGS-MJ-0054. All specimens were covered with ammonium chloride prior to photography. Scale bar equals $5 \mathrm{~mm}$.

surface); proximal articulation slightly oblique to long axis of manus. Distal margin with swellings at articulation with dactylus. Fixed finger short, straight and pointed. Dactylus short and robust, highest proximally, without any apparent armature. Lateral propodal surfaces, without cuticle, show fine, scabrous ornamentation; cuticular surface is covered also with numerous, uniformly arranged tubercles.

Remarks. - The chelae are superficially similar to those found in the Oxfordian sponge bioherms of Dobrogea, Romania (Feldmann et al. 2006) and non-biohermal facies of the Pieniny Klippen Belt, Slovakia (Hyžný et al. 2011). Feldmann et al. (2006) described the upper margin of their "indeterminate chela sp. 1" as having three tiny spines; these are not present/preserved in the material of Stránská skála.

In contrast to the occurrences discussed above, the Czech material exhibit propodi articulated with dactyli, a condition which has so far not been mentioned in any published report on the Upper Jurassic reefal facies decapod assemblages. Unfortunately, the specimens are not preserved in direct association with carapaces; thus, closer identification is not possible. We can only speculate on the identity of the chelae as belonging to some species of Goniodromites, as the majority of specimens of primitive brachyurans recovered from Stránská skála are goniodromitids and the same is true for the sponge bioherms of Dobrogea (Feldmann et al. 2006, Franțescu 2011).

Quenstedt (1858, pl. 95, figs 49-51) illustrated three claws associated with primitive crabs; one of them (Quenstedt 1858, pl. 95, fig. 50) bears strong resemblance to the chelae from Stránská skála.

Étallon (1859, pl. 3, figs 3, 9) depicted two claws; he assigned them to Pithonoton meyeri Étallon, 1859 (= Longodromites meyeri) and $P$. quadratum, respectively. None of them fits the morphotype from Stránská skála.

Von Meyer (1860, pl. 23, fig. 16) figured two chelae as belonging to Prosopon elongatum von Meyer, 1860 (= Pithonoton elongatum) and three additional chelae without assignment to any crab species. All of them differ from the Stránská skála material in possessing proportionally longer fingers.

\section{Discussion}

Differential decapod diversity. - Oppenheimer (1926) mentioned more than 90 species of macrofauna from the Oxfordian of Stránská skála, including corals, cephalopods, bivalves, gastropods, brachiopods, polychaetes, crustaceans, and echinoderms. According to a microfacies analysis conducted by Eliáš (1981), the environment of the Stránská skála was very shallow marine and represents the transition between the carbonate platform and the shelf lagoon. The exposed carbonate breccias represent the margins of the carbonate platform and separated the platform from the shelf lagoon. 

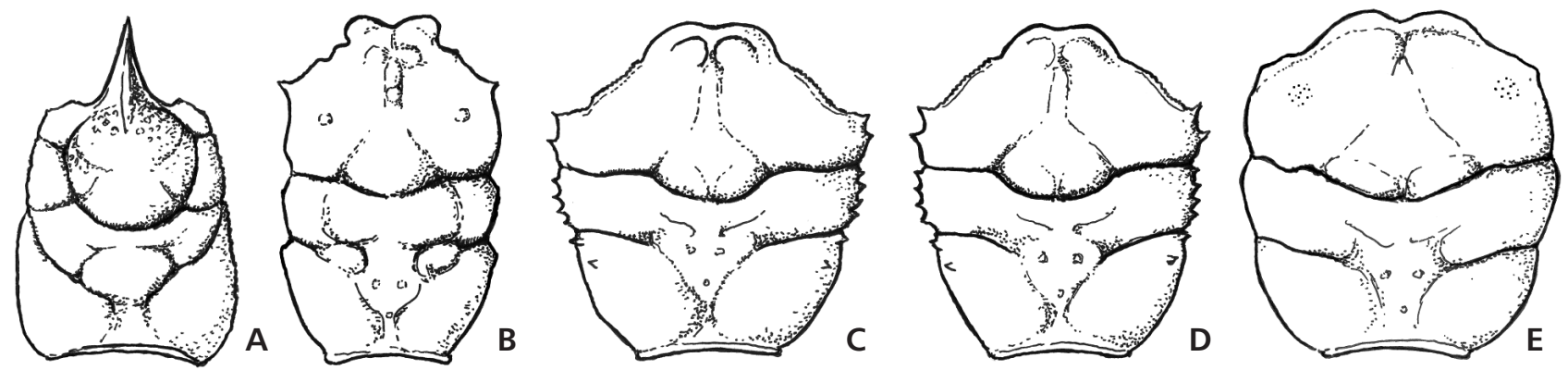

Figure 8. Schematic reconstructions of decapod carapaces from the Oxfordian of Stránská skála. Carapace ornamentation is largely omitted. - A - Gastrosacus wetzleri von Meyer, 1854. • B - Longodromites angustus (Reuss, 1858). • C - Goniodromites narinosus Franțescu, 2011. •D - Goniodromites serratus Beurlen, 1929. • E - Eodromites grandis (von Meyer, 1857). Reconstructions are based on the material from Stránská skála and the figured type material. Due to incompleteness of the material, the reconstruction of Eomunidopsis cf. E. neojurensis (Patrulius, 1959) has not been included.

The corals occurring at the Stránská skála are not very diverse; Eliášová (1994) reported only 11 taxa, of which two are in open nomenclature. The assemblage is dominated by Isastrea helianthoides (Goldfuss, 1826), which is characteristic for the Upper Jurassic (Oxfordian-Kimmeridgian) coral build-ups (e.g. Turnšek 1997, Pandey et al. 2009). According to Eliášová (1994) the corals in the Brno vicinity constituted a simple lenticular biostrome, whereas the plateau was a part of a vast shallow marine carbonate platform on the southern (passive) margin of the Western European platform (Eliáš 1981, Eliášová 1994, Adámek 2005). Later, after the deposition of the Stránská skála coral buildup, the sediment prograded into the lagoon.

Previous investigations have shown that Upper Jurassic coral reef faunas, in terms of decapods, were generally diverse and robust (Schweitzer et al. 2007b, Franțescu 2011). Schweitzer et al. (2007b) compared the differential diversity among the Upper Jurassic sponge-algal and coralline decapod assemblages in Romania and concluded that many more genera had been specialized for coral reef habitats than for sponge ones. This was perhaps due to the shallower, better oxygenated and better illuminated environment of coral reefs as well as the wide variety of coral morphologies and the presence of more niches and physical spaces there. In this respect, the rather low decapod diversity of Stránská skála compared to other Upper Jurassic localities with preserved coral reefs (Table 3) may look surprising. In terms of diversity it is comparable to the roughly coeval sponge-algal environments of Romania (Feldmann et al. 2006, Schweitzer et al. 2007a; see Table 3). This discrepancy may be explained by collecting bias at Stránská skála. The material studied herein represents old collections; the exact position of specimens within the section cannot be traced, nor can be determined the specific place at the locality. Further collecting at Stránská skála is not possible anymore (see above) and, thus, only the discovery of other old collections can add more data about the true diversity of decapod crustaceans there. Potentially, surveys of similar Polish and Romanian localities could be a nice comparative example in this respect.

Older studies (e.g. Collins \& Wierzbowski 1985) underestimated the diversity of decapods compared to the most-recent research (Feldmann et al. 2006; Schweitzer et al. 2007a, b; Franțescu 2011; Fraaije et al. 2012a-c, 2014; Starzyk et al. 2011, 2012; Starzyk 2013), mostly because new insights into the systematics of paguroids, galatheoids and primitive brachyurans called for major taxonomic revisions. These revisions significantly influenced the number of observed species of fossil decapods. Thus, it is not surprising that the diversity of decapods at Ghergheasa (Muțiu \& Bădăluță 1971) and Stránská skála (herein) is rather low, because Ghergheasa has not been restudied in light of the new taxonomic revisions (e.g. Feldmann et al. 2006; Schweitzer et al. 2007a; Schweitzer \& Feldmann 2008, 2009; Franțescu 2011; Robins et al. 2012; Starzyk et al. 2012). Additionally, only limited attention has been paid to Stránská skála in terms of decapod identification. In fact, since Oppenheimer (1926), no systematic treatment of the Oxfordian decapods of Stránská skála has been published. The species composition of Stránská skála is very close to that of the lower Tithonian of Woźniki, Poland (Patrulius 1966), although the latter association is more diverse. This may also indicate strong collecting bias in the case of Stránská skála.

More precise stratigraphic data on studied faunas appear to be crucial in resolving the true diversity of localities. Unrelated assemblages from different time horizons can be mixed when collecting within debris, especially when the studied sections span more than one ammonite zone (Starzyk et al. 2011, 2012; Starzyk 2013). Since many known decapod localities are now inaccessible or demolished, the true diversity of some localities, such as Stránská skála may never be known. This is also a reason why we did not compare the Stránská skála assemblage with the Tithohian-Berriasian assemblages of Ernstbrunn 
Table 3. Differential diversity of decapod crustacean taxa at selected Upper Jurassic localities.

\begin{tabular}{llcl}
\hline Locality & Age & Genera/species & Reference \\
\hline Coral environment & & & \\
Stránská skála (CZ) & Oxfordian & $5 / 6$ & herein \\
Ghergheasa (RO) & Tithonian & $6 / 7$ & Muțiu \& Bădăluță (1971) \\
Topalu/Piatra (RO) & Oxfordian/Kimmerdigian & $7 / 10$ & Franțescu (2011) \\
Purcareni (RO) & Tithonian & $16 / 24$ & Patrulius (1966), Shirk (2006) \\
Sinaia/Moroeni (RO) & Tithonian & $20 / 38$ & Patrulius (1959, 1966), Schweitzer et al. (2007b) \\
\hline Sponge-algal environment & & & \\
Gura Dobrogei (RO) & Oxfordian & $4 / 4$ & Schweitzer et al. (2007a) \\
Cheia (RO) & Oxfordian & $3 / 5$ & Feldmann et al. (2006) \\
Kroczyce (PL) & Oxfordian & $3 / 5$ & Głowniak \& Wierzbowski (2007) \\
Grabowa (PL) & Oxfordian & $5 / 9$ & Głowniak \& Wierzbowski (2007) \\
Wysoka (PL) & Oxfordian & $8 / 13$ & Przybylski et al. (2010) \\
Niegowonice (PL) & Oxfordian & $9 / 22$ & Głowniak (2006) \\
Bzów (PL) & Oxfordian & $12 / 24$ & Matyja \& Wierzbowski (1994) \\
Ogrodzieniec (PL) & Oxfordian & $13 / 24$ & Głowniak (2006) \\
\hline
\end{tabular}

and Štramberk, which are extremely rich but their stratigraphic span is not limited to a single stage (Houša et al. 1996; Vašíček \& Skupien 2004, 2005; Schneider et al. 2013).

Parasitized decapods. - Bopyriform swellings (as termed by Wienberg Rasmussen et al. 2008), which typically occur on the branchial regions, were recently named Kanthyloma crusta by Klompmaker et al. (2014). These swellings are known from many Upper Jurassic decapod assemblages (Bachmayer 1948, Houša 1963, Radwański 1972, Wienberg Rasmussen et al. 2008, Robins et al. 2012, Klompmaker et al. 2014).

The studied material from Stránská skála contains three infested specimens (out of 36); two of them were infested on the right side, and one specimen was infested on the left side. The sample, however, is too small to draw any conclusions regarding the preference for the left or right branchial side for infestation. Based on statistical data from the Albian of Koskobilo, Spain, Klompmaker et al. (2014) concluded that there is no statistical preference for either the left or right branchial side for infestation on the assemblage level.

Interestingly, the rate of infestation seems rather high in the Stránská skála assemblage, reaching $8.33 \%$. For comparison, Bachmayer (1955) reported the rate of infestation to be $2 \%$ out of 3000 decapod specimens from the Tithonian of Ernstbrunn (Austria), Houša (1963) reported $3.82 \%$ out of 890 specimens from the Tithonian of Stramberk (Czech Republic) and Radwański (1972) reported less than $1.4 \%$ out of more than 500 specimens. For Cretaceous assemblages the rate of infestation seems to be comparable; for instance Klompmaker et al. (2014) noted that $4.2 \%$ out of 874 decapod specimens from the Albian of
Koskobilo quarry (Spain) were infected. It should, however, be noted that not all species from the studied assemblages possess swellings, but rather there is a preference for certain taxa. At the higher taxonomic level, galatheoid specimens usually are more afflicted than brachyuran families (Klompmaker et al. 2014). From Stránská skála, however, no infested galatheoids are known. This can be explained with the small study sample. A relatively high percentage of infestation may be a consequence of collecting bias; carapaces with swellings are presumably more attractive to collectors. Although larger sample sizes may represent more accurate proportions of infested taxa, it is highly dependent upon the methodology of the collectors. If all decapod specimens regardless of species and condition were collected (i.e. no collecting bias), a truer picture of infestation level may be gleaned. With most museumbased research, data like this is not possible.

Taxonomy of isolated chelipeds. - Isolated cheliped elements are virtually always present together with carapaces at Upper Jurassic localities, but so far they have not been reported in close association with each other; thus, the identification of the chelipeds remains obscure. Feldmann et al. (2006) considered the association of chelae with carapaces reported by Quenstedt (1858), Étallon (1859) and von Meyer (1860) as circumstantial, i.e. their closer identification is not possible. We concur with Feldmann et al. (2006), but add that describing and depicting cheliped elements is a crucial step in understanding their taxonomic significance. In fact, only a few authors have depicted the isolated chelae from Jurassic localities (von Meyer 1860, Feldmann et al. 2006, Crônier \& Boursicot 2009, Hyžný et al. 2011), although tens of publications on Jurassic brachyurans exist. In this respect, for the brachyurans of the Lower 
and Upper Cretaceous the knowledge of cheliped morphology is more advanced and several claw types have been successfully matched to the carapaces (Jagt et al. 2010, Kočová Veselská et al. 2014, Hyžný \& Kroh 2015).

Isolated cheliped elements, although difficult to treat taxonomically, exhibit characters that can be matched to a certain mode of life (e.g. armature of fingers, finger length, spatulate tips, etc.) and can thus say something about the ecological niches the decapods occupied within the ancient ecosystems. Robust propodi with short fingers in goniodromitid crabs may indicate feeding habits that involved scraping algal surfaces or detritus feeding.

Parataxonomy (i.e. usage of "form" taxa) is another way to deal with cheliped fragments, but due to widespread convergence in shape of decapod chelae and without more comparative studies using Upper Jurassic material it is difficult to propose characters of taxonomic importance. Parataxonomy has been recently proposed for sixth abdominal tergites of pylochelid hermit crabs (Fraaije et al. 2012a, 2013b); however, for isolated brachyuran chelae, the parataxonomy is seemingly avoided (see discussions in Jagt et al. 2010, Kočová Veselská et al. 2014, Hyžný \& Kroh 2015).

\section{Acknowledgements}

Nela Doláková (IGS-MJ), Peter Klepsatel (formerly SNM), Martin Mazuch (CHMHZ) and Barbara Zahradníková (SNM) are thanked for facilitating access to the material deposited at their respective institutions. Tomáš Kočí helped with tracking part of the old collections from Stránská skála now deposited at CHMHZ. Barry W.M. van Bakel (Oertijdmuseum de Groene Poort, Boxtel, the Netherlands) is thanked for fruitful discussion on the usage of the term "augenrest". The manuscript benefited from the constructive criticism of Carrie E. Schweitzer (Kent State University, Ohio, USA) and an anonymous reviewer. This work was supported by the Slovak Research and Development Agency under the contracts No. APVV-0644-10 and No. APVV-0436-12.

\section{References}

ADÁmEK, J. 2005. The Jurassic floor of the Bohemian Massif in Moravia - geology and paleogeography. Bulletin of Geosciences 80, 291-305.

Alcock, A. 1900. Materials for a carcinological fauna of India. No. 5. The Brachyura Primigenia, or Dromiacea. Journal of the Asiatic Society of Bengal 68, 123-169.

Bachmayer, F. 1947. Die Crustaceen aus dem Ernstbrunnerkalk der Jura-Klippenzone zwischen Donau und Thaya. Jahrbuch der Geologischen Bundesanstalt 90, 35-43.

Bachmayer, F. 1948. Pathogene Wucherungen bei jurassischen Dekapoden. Sitzungsberichte der Österreichischen Akademie der Wissenschaften, mathematisch-naturwissenschaftliche Klasse 57(1), 263-266.
Bachmayer, F. 1955. Die fossilen Asseln aus den Oberjuraschichten von Enstbrunn in Niederösterreich und von Stramberg in Mähren. Sitzungsberichte der Österreichischen Akademie der Wissenschaften, mathematisch-naturwissenschaftliche Klasse 64(1), 255-273.

BertLing, M. \& InSALACO, E. 1998. Late Jurassic coral/microbial reefs from the northern Paris Basin - facies, palaeoecology and palaeobiogeography. Palaeogeography, Palaeoclimatology, Palaeoecology 139, 139-175.

DOI 10.1016/S0031-0182(97)00125-9

Beurlen, K. 1929. Untersuchungen über Prosoponiden. Zentralblatt für Mineralogie, Geologie und Paläontologie (B, Geologie und Paläontologie) 1929, 125-142.

BeurLen, K. 1932. Brachyurenreste aus dem Lias von Bornholm mit Beiträgen zur Phylogenie und Systematik der Brachyuren Dekapoden. Paläontologische Zeitschrift 14, 52-66. DOI 10.1007/BF03041617

BlaschKe, F. 1911. Zur Tithonfauna von Stramberg in Mähren. Annalen des Kaiserlich-Königlichen Naturhistorischen Hofmuseums 25, 143-221.

Cariou, E., Enay, R., Atrops, F., Hantzpergue, P., Marchand, D. \& Rioult, M. 1997. 9. - Oxfordien, 79-86. In CARIou, E. \& HANTZPERgue, P. (eds) Biostratigraphie du Jurassique ouesteuropéen et méditerranéen: zonations parallèles et distribution des invertébrés et microfossiles. Bulletin des centres de recherches Exploration-produktion Elf-Aquitaine, Mémoire 17.

CARTER, J. 1898. A contribution to the palaeontology of the decapod Crustacea of England. Quarterly Journal of the Geological Society of London 54(1), 15-44.

DOI 10.1144/GSL.JGS.1898.054.01-04.06

Collins, J.S.H., FraAye, R.H.B. \& JAGT, J.W.M. 1995. Late Cretaceous anomurans and brachyurans from the Maastrichtian type area. Acta Palaeontologica Polonica 40, 165-210.

Collins, J.S.H. \& Wierzbowski, A. 1985. Crabs from the Oxfordian sponge megafacies of Poland. Acta Geologica Polonica 35, 73-88.

Crônier, C. \& Boursicot, P.-Y. 2009. A new decapod crustacean faunule from the Middle Jurassic of north-west France. Palaeontology 52, 1275-1289.

DOI 10.1111/j.1475-4983.2009.00896.x

ELIÁš, M. 1969. Zpráva o sedimentologickém výzkumu brněnské jury. Zprávyo geologických výzkumech v roce 1968, 216-219.

EliÁš, M. 1981. Facies and paleogeography of the Jurassic of the Bohemian Massif. Sborník geologických věd, Geologie 35, 75-114.

EliÁš, M. \& EliášovÁ, H. 1984. Facies and palaeogeography of the Jurassic in the western part of the Outer Flysch Carpathians in Czechoslovakia. Sborník geologických věd, Geologie 39, 105-170.

ElíśšovÁ, H. 1994. Scléractinaires de Stránská skála (Oxfordien inférieur/supérieur, Brno, Moravie, République tchèque). Věstník Českého geologického ústavu 69, 65-70.

ÉtAllon, A. 1859. Description des crustacés de la Haute-Saône et du Haut-Jura. Bulletin de la Societé géologique de France, série 2 16, 169-205.

Feldmann, R.M., LAZĂR, I. \& SchweitZer, C.E. 2006. New crabs (Decapoda: Brachyura: Prosopidae) from Jurassic (Oxfordian) sponge bioherms of Dobrogea, Romania. Bulletin of the Mizunami Fossil Museum 33, 1-20.

Feldmann, R.M. \& Portell, R.W. 2007. First report of 
Costacopluma Collins and Morris, 1975 (Decapoda: Brachyura: Retroplumidae) from the Eocene of Alabama, U.S.A. Journal of Crustacean Biology 27, 90-96. DOI 10.1651/S-2712.1

FraAiJe, R.H.B., Artal, P., Van Bakel, B.W.M., Jagt, J.W.M. \& KLOMPMAKER, A.A. 2013b. An array of sixth abdominal tergite types of paguroid anomurans (Crustaceans) from the mid-Cretaceous of Navarra, northern Spain. Netherlands Journal of Geosciences - Geologie en Mijnbouw 92, 109-117.

FraaiJe, R.H.B., KrZemiński, W., Van BaKel, B.W.M., KRZEMińsKa, E. \& JAGT, J.W.M. 2012a. The earliest record of pylochelid hermit crabs from the Late Jurassic of southern Poland, with notes on paguroid carapace terminology. Acta Palaeontologica Polonica 57, 647-654. DOI 10.4202/app.2011.0002

FraAije, R.H.B., Krzemiński, W., Van Bakel, B.W.M., KRZEMIŃSKA, E. \& JAGT, J.W.M. 2012b. The earliest record of a diogenid hermit crab from the Late Jurassic of the southern Polish Uplands, with notes on paguroid carapace terminology. Acta Palaeontologica Polonica 57, 655-660. DOI 10.4202/app.2011.0052

Fraaije, R.H.B., Krzemiński, W., Van Bakel, B.W.M., KRZEMIŃSKA, E. \& JAGT, J.W.M. 2012c. The sixth abdominal tergites of paguroid anomurans - a newly recognized crustacean macrofossil type. Neues Jahrbuch für Geologie und Paläontologie, Abhandlungen 266, 115-122. DOI 10.1127/0077-7749/2012/0273

Fraaije, R.H.B., Krzemiński, W., Van Bakel, B.W.M., KRZEMińsKa, E. \& JAGT, J.W.M. 2014. New Late Jurassic symmetrical hermit crabs from the southern Polish Uplands and early paguroid diversification. Acta Palaeontologica Polonica 59, 681-688.

Fraaije, R.H.B., Van Bakel, B.W.M., Guinot, D. \& Jagt, J.W.M. 2013a. A new Middle Jurassic (Bajocian) homolodromioid crab from northwest France; the earliest record of the Tanidromitidae. Boletín de la Sociedad Geológica Mexicana 65, 249-254.

FraAye, R.H.B. \& Collins, J.S.H. 1996. Two new decapods crustaceans from the Portlandian of Dorset, England. Proceedings of the Geologists' Association 107, 323-326.

FRANȚESCU, O.D. 2011. Brachyuran decapods (including five new species and one new genus) from Jurassic (Oxfordian-Kimmeridgian) coral reef limestones from Dobrogea, Romania. Neues Jahrbuch für Geologie und Paläontologie, Abhandlungen 259, 271-297.

DOI 10.1127/0077-7749/2010/0110

Gemmellaro, G.G. 1869. Studi paleontologici sulla fauna del calcare a Terabratula janitor del Nord si Sicilia, 11-18. Lao, Palermo.

GŁowniaK, E. 2006. Correlation of the zonal schemes at the Middle - Upper Oxfordian (Jurassic) boundary in the Submediterranean Province: Poland and Switzerland. Acta Geologica Polonica 56, 33-50.

GŁowniak, E. \& WierzBowski, A. 2007. Taxonomical revision of the perisphinctid ammonites of the Upper Jurassic (Plicatilis to Planula Zones) described by Józef Siemiradzki (1891) from the Kraków Upland. Volumina Jurassica 5, 27-137.

Goldfuss, A. 1826-1829. Petrefacta Germaniae. Theil 1, 2. 168 pp. Arnz und Comp., Düsseldorf.

Guinot, D. \& Richer de Forges, B. 1995. Crustacea Decapoda
Brachyura: Révision de la familie de Homolidae de Haan, 1841, 1283-517. In Crosnier, A. (ed.) Résultats des Campagnes Musorstom, volume 13. Mémoires du Muséum national d'Histoire naturelle 13.

HaAn, W. DE 1833-1850. Crustacea. In Siebold, P.F. von (ed.) Fauna Japonica sive Descriptio Animalium, quae in Itinere per Japoniam, Jussu et Auspiciis Superiorum, qui summum in India Batava Imperium Tenent, Suspecto, Annis 1823-1830 Collegit, Notis, Observationibus et Adumbrationibus Illustravit. i-xvii, i-xxxi, i-xvi, 243 pp. Müller et Co., Lugduni Batavorum [= Leyden].

Houša, V., Krs, M., Krsová, M. \& Pruner, P. 1996. Magnetostratigraphy of Jurassic-Cretaceous limestones in the Western Carpathians, 185-194. In Morris, A. \& TARLING, D.H. (eds) Paleomagnetism and textonics of the Mediterranean region. Geological Society, Special Publications 105.

HyŽNÝ, M. \& KROH, A. 2015. Barremian decapod crustaceans from Serre de Bleyton (Drôme, SE France). Annalen des Naturhistorischen Museums in Wien A 117, 121-152.

HyžNÝ, M., SchlöGl, J. \& KRoBicki, M. 2011. Tanidromites insignis (von Meyer, 1857) (Crustacea: Decapoda: Brachyura) from Late Jurassic non-biohermal facies of the Western Tethys (Pieniny Klippen Belt, Western Carpathians, Slovakia). Neues Jahrbuch für Geologie und Paläontologie, Abhandlungen 262, 213-226. DOI 10.1127/0077-7749/2011/0193

Jagt, J.W.M., FraAiJe, R.H.B., Van Bakel, B.W.M. \& Artal, P. 2010. Necrocarcinus ornatissimus Forir, 1887, and Prehepatus werneri Fraaye \& Collins, 1987 (Upper Maastrichtian, The Netherlands) revisited, with notes on other Cretaceous dynomenid crabs (Decapoda, Brachyura), 173-195. In CAStro, P., Davie, P.J.F., NG, P.K.L. \& Richer de Forges, B. (eds) Brachyura: a Homage to Danièle Guinot. Crustaceana Monographs 11.

Jaroš, Z. \& Zapletal, K. 1928. Geologische Exkursion auf den Hády-Berg u. die Stránská skála bei Brünn. Mineralogicko-geologický oddíl Moravského zemského muzea v Brně, $1-9$.

Karasawa, H. \& Kato, H. 2007. New prosopid crabs (Crustacea, Decapoda, Brachyura) from the Upper Jurassic Torinosu Group, Sikoku, Japan, 62-65. In Garassino, A., Feldmann, R.M. \& Teruzzi, G. (eds) $3^{\text {rd }}$ Symposium on Mesozoic and Cenozoic Decapod Crustaceans. Memorie della Società Italiana di Scienze Naturali e del Museo Civico di Storia Naturale di Milano 35(2).

Karasawa, H., Ohara, M. \& Kato, H. 2008. New records for Crustacea from the Arida Formation (Lower Cretaceous, Barremian) of Japan. Boletín de la Sociedad Geológica Mexicana 60, 101-110.

Klompmaker, A.A., Artal, P., Van Bakel, B.W.M., Fraaije, R.H.B. \& JAGT, J.W.M. 2014. Parasites in the fossil record: A cretaceous fauna with isopod-infested decapod crustaceans, infestation patterns through time, and a new ichnotaxon. PLoS ONE 9(3), e92551. DOI 10.1371/journal.pone.0092551

Klompmaker, A.A., Feldmann, R.M., Robins, C.M. \& SChweitzer, C.E. 2012a. Peak diversity of Cretaceous galatheoids (Crustacea, Decapoda) from northern Spain. Cretaceous Research 36, 125-145.

DOI 10.1016/j.cretres.2012.03.003

Klompmaker, A.A., Feldmann, R.M. \& Schweitzer, C.E. 2012 b. 
A hotspot for Cretaceous goniodromitids (Decapoda: Brachyura) from reef associated strata in Spain. Journal of Crustacean Biology 32, 780-801. DOI 10.1163/193724012X635340

KLompMaKer, A.A., HYŽNÝ, M. \& JAKOBSEn, S.L. 2015. Taphonomy of decapod crustacean cuticle and its effect on the appearance as exemplified by new and known taxa from the Cretaceous-Danian crab Caloxanthus. Cretaceous Research 55, 141-151. DOI 10.1016/j.cretres.2014.11.011

Kočová Veselská, M., Kočí, T. \& Kubajko, M. 2014. Dynomenid crabs (Decapoda, Brachyura) and stalked barnacles (Cirripedia, Scalpelliformes) from upper Cenomanianlower Turonian nearshore, shallow-water strata in the Bohemian Cretaceous Basin, Czech Republic, 49-81. In FrAAIJE, R.H.B., HYŽNÝ, M., JAGT, J.W.M., KROBICKI, M. \& VAN BAKEL, B.W.M. (eds) Proceedings of the $5^{\text {th }}$ Symposium on Mesozoic and Cenozoic Decapod Crustaceans, Krakow, Poland, 2013: A tribute to Pál Mihály Müller. Scripta Geologica 147.

Koutek, J. 1926. Příspěvek k poznání rohovcových vápenců jurských na Stránské skále u Brna. Věstník Státního geologického ústavu 2, 172-182.

Krobicki, M. \& Zatoń, M. 2008. Middle and Late Jurassic roots of brachyuran crabs: Palaeonvironmental distribution during their early evolution. Palaeogeography, Palaeoclimatology, Palaeoecology 263, 30-43. DOI 10.1016/j.palaeo.2008.01.025

Latreille, P.A. 1802-1803. Histoire naturelle, générale et particulière des Crustacés et des Insectes. 468 pp. F. Dufart, Paris.

Linnaeus, C. 1758. Systema Naturae per Regna tria Naturae, secundum classes, ordines, genera, species, cum characteribus, differentiis, synonymis, locis (ed. 10). 824 pp. Laurentii Salvii, Holmiae.

Lörenthey, E. \& Beurlen, K. 1929. Die fossilen Dekapoden der Länder der Ungarischen Krone. Geologica Hungarica, Series Palaeontologica 3, 1-421.

MacLeay, W.S. 1838. On the brachyurous decapods Crustacea brought from the Cape by Dr. Smith, 53-71. In SMITH, A. Illustrations of the Annulosa of South Africa; consisting chiefly of figures and descriptions of the objects of natural history collected during an expedition into the interior of South Africa, in the years 1834, 1835, and 1836; fitted out by "The Cape of Good Hope Association for Exploring Central Africa..." Smith, Elder and Company, London.

Matyja, B.A. \& Wierzbowski, A. 1994. On correlation of Submediterranean and Boreal ammonite zonations of the Middle and Upper Oxfordian: new data from Central Poland. Geobios 17, 351-358. DOI 10.1016/S0016-6995(94)80154-1

Meyer, H. von 1835. Briefliche Mitteilungen. Neues Jahrbuch für Mineralogie, Geognosie, Geologie und Petrefakten-Kunde 1835, 1-329.

Meyer, H. von 1840. Neue Gattungen fossiler Krebse aus Gebilden vom bunten Sandsteine bis in die Kreide. 23 pp. E. Schweizerbart, Stuttgart.

Meyer, H. von 1851. Beschreibung der fossilen Decapoden, Fische, Batrachier und Säugetiere aus den tertiären Süsswassergebilden des nördlichen Böhmens. Palaeontographica $2,43-73$.

MeYer, H. von 1854 [imprint 1856]. Jurassische und Triassische Crustaceen. Paleontographica 4, 44-55.
Meyer, H. von 1857. Briefliche Mitteilungen. Neues Jahrbuch für Mineralogie, Geologie, Geognosie und Paläontologie, 556.

Meyer, H. von 1860. Die Prosoponiden oder die Familie der Maskenkrebse. Palaeontographica 7, 183-222.

Milne-Edwards, A. 1865. Note sur deux nouveaux Crustacés fossiles du terrain néocomien du Départementde l'Yonne. Bulletin de la Société des Sciences historiques et naturelles de l'Yonne 19, 341-347.

Moericke, W. 1889. Die Crustaceen der Stramberger Schichten. Palaeontographica, Supplement 2(6), 43-72.

Müller, P., Krobicki, M. \& Wehner, G. 2000. Jurassic and Cretaceous primitive crabs of the family Prosopidae (Decapoda: Brachyura) - their taxonomy, ecology and biogeography. Annales Societatis Geologorum Poloniae 70, 49-79.

Muțiu, R. \& BĂDĂLuȚă, A. 1971. La présence des décapodes anomures et dromiacés dans les calcaires tithoniques de Plate-Forme Moësienne. Annales Instituti Geologii Publici Hungarici 54, 245-525.

Oppenheimer, J. 1926. Der Malm der Stránská skála bei Brünn. Časopis Moravského muzea v Brně, Vědy př́rodní 24, 1-31.

Ortmann, A.E. 1898. Gliederfüssler: Arthropoda, 1057-1168. In Gerstäcker, A. \& Ortmann, A.E. (eds) Dr. H.G. Bronn's Klassen und Ordnungen des Thier-Reichs, wissenschaftlich dargestellt in Wort und Bild Bd. V, Abt. 2 (Crustacea), 2 Hälfte (Malacostraca). C.F. Winter'sche Verlagshandlung, Leipzig.

PANDEY, D.K., FÜrsich, F.T. \& BARON-SZABO, R. 2009. Jurassic corals from the Jaisalmer Basin, western Rajasthan, India. Zitteliana A48/49, 13-37.

PAtrulius, D. 1959. Contribution à la systématique des Décapodes néojurassiques. Revue de Géologie et Géographie 3, 249-257.

Patrulius, D. 1966. Les Décapodes du Tithonique inférieur de Woźniki (Carpates Polonaises Occidentales). Annales de la Société géologique de Pologne 36, 495-517.

Pelseneer, P. 1886. Notice sur les Crustacés décapodes du Maastrichtien du Limbourg. Bulletin du Musée royal d'histoire naturelle de Belgique 4(3), 161-175.

Przybylski, P.A., GŁowniak, E., OGg, J.G., ZióŁkowski, P., Sidorczuk, M., Gutowski, J. \& Lewandowski, M. 2010. Oxfordian magnetostratigraphy of Poland and its correlation to Sub-Mediterranean ammonite zones and marine magnetic anomalies. Earth and Planetary Science Letters 289, 417-432. DOI 10.1016/j.eps1.2009.11.030

Quenstedt, F.A. 1856-1858. Der Jura. 842 pp. H. Lauppschen Buchhandlung, Tübingen.

RADWAŃSKI, A. 1972. Isopod infected prosoponids from the Upper Jurassic of Poland. Acta Geologica Polonica 22, 499-506.

Remeš, M. 1895. Beiträge zur Kenntnis der Crustaceen der Stramberger Schichten. Bulletin International de l'Académie des Sciences de Bohème 2, 200-204.

Reuss, A.E. 1858. Über kurzschwänzige Krebse im Jurakalke Mährens. Sitzungsberichte der Kaiserlichen Akademie der Wissenschaften, Mathematisch-naturwissenschaftliche Klasse 31, 5-13.

Reuss, A.E. 1859. Zur Kenntnis fossiler Krabben. Denkschrifte der Akademie der Wissenschaften zu Wien 17, 1-90.

Risso, A. 1815. Histoire naturelle des Crustacés des environs de Nice. 175 pp. A la Librairie grecque-latine-allemande, Paris.

Robins, C.M., Feldmann, R.M. \& Schweitzer, C.E. 2013. Nine 
new genera and 24 new species of Munidopsidae (Decapoda: Anomura: Galatheoidea) from the Jurassic Ernstbrunn Limestone of Austria, and notes on fossil munidopsid classification. Annalen des Naturhistorischen Museums in Wien A 115, 167-251.

Robins, C.M., Klompmaker, A.A., FraAiJe, R.M.B., van BaKel, B.W.M. \& JAGT, J.W.M. 2015. New material and redescription of Gastrosacus wetzleri von Meyer, 1851 (Decapoda, Anomura, Galatheoidea) from the Late Jurassic of southern Germany. Neues Jahrbuch für Geologie und Paläontologie 275, 83-91. DOI 10.1127/njgpa/2015/0452

Ruiz de Gaona, M. 1943. Nota sobre Crustáceos Decápodos de la cantera del Monte Orobe (Alsasua). Boletin Real Sociedad Española de Historia Natural 40, 425-433.

SAmouelle, G. 1819. The entomologist's useful compedium; or an introduction to the knowledge of British insects, comprising the best means of obtaining and preserving them, and a description of the apparatus generally used; together with the genera of Linné, and the modern method of arranging the classes Crustacea, Myriapoda, Spiders, Mites and Insects, from their affinities and structure, according to the views of Dr. Leach. Also an explanation of the terms used in entomology; a calendar of the times of appearance and usual situations of near 3,000 species of British insects; with instructions for collecting and fitting up objects for the microscope. 496 pp. Thomas Boys, London.

Schneider, S., Harzhauser, M., Kroh, A., Lukeneder, A. \& Zuschin, M. 2013. Ernstbrunn Limestone and Klentnice Beds (Kimmeridgian-Berriasian; Waschberg-Ždánice Unit; NE Austria and SE Czech Republic): state of the art and bibliography. Bulletin of Geosciences 88, 105-130. DOI 10.3140/bull.geosci.1360

Schweitzer, C.E. \& Feldmann, R.M. 2008 [imprint 2007]. A new classification for some Jurassic Brachyura (Crustacea: Decapoda: Brachyura: Homolodromioidea): families Goniodromitidae Beurlen, 1932 and Tanidromitidae new family. Senckenbergiana lethaea 87, 119-156.

Schweitzer, C.E. \& Feldmann, R.M. 2009. Revision of the Prosopinae sensu Glaessner, 1969 (Crustacea: Decapoda: Brachyura) including four new families, four new genera, and five new species. Annalen des Naturhistorischen Museums in Wien A 110, 55-121.

Schweitzer, C.E., Feldmann, R.M. \& LaZĂR, I. 2007a. Decapods from Jurassic (Oxfordian) sponge megafacies of Dobrogea, Romania and reconsideration of Nodoprosopon Beurlen, 1928. Neues Jahrbuch für Geologie und Paläontologie Abhandlungen 244, 99-113. DOI 10.1127/0077-7749/2007/0244-0099

Schweitzer, C.E., Feldmann, R.M., Shirk, A.M. \& Lazăr, I. 2007b. Differential diversity in Jurassic sponge-algal and coralline communities, Romania, 91-94. In GARAssino, A., Feldmann, R.M. \& Teruzzi, G. (eds) $3^{\text {rd }}$ Symposium on Mesozoic and Cenozoic Decapod Crustaceans. Memorie della Società Italiana di Scienze Naturali e del Museo Civico di Storia Naturale di Milano 35(2).

SHIRK, A. 2006. A novel assemblage of decapod Crustacea from a Tithonian coral reef olistolith, Purcăreni, Romania: systematical arrangement and biogeographical perspective. $191 \mathrm{pp}$. Unpublished Master thesis, Kent State University, Ohio.
STARZYK, N. 2013. Jurassic crabs: new characters of carapace diagnostic to known tanidromitid species. Neues Jahrbuch für Geologie und Paläontologie, Abhandlungen 269, 173-187. DOI 10.1127/0077-7749/2013/0343

Starzyk, N., KRZemińska, E. \& KrZemiński, W. 2011. Intraspecific variation in the Jurassic crab Bucculentum bucculentum (Decapoda: Homolodromioidea: Bucculentidae). Neues Jahrbuch für Geologie und Paläontologie, Abhandlungen 260, 203-210. DOI 10.1127/0077-7749/2011/0169

StarzyK, N., KrZEmińsKa, E. \& KrZemińsKi, W. 2012. A new crab species from the Oxfordian of Poland (Decapoda: Brachyura: Goniodromitidae). Neues Jahrbuch für Geologie und Paläontologie, Abhandlungen 263, 143-153. DOI 10.1127/0077-7749/2012/0219

TURNŠEK, D. 1997. Mesozoic corals of Slovenia. 512 pp. Znanstvenoraziskovalni center SAZU, Ljubljana.

Uhlig, V. 1881. Die Jurabildungen in der Umgebung von Brünn. Beiträge zur Paläontologie von Österreich-Ungarn 1,1-182.

Van Straelen, V. 1940. Crustacés décapodes nouveaux Crétacique de la Navarre. Bulletin du Musée royal d'Histoire naturelle de Belgique 16, 1-5.

VAšičEK, Z. 1973. Předběžná zpráva o makropaleontologickém výzkumu úseku Morava "střed" za r. 1973. MS Geofond, Praha.

VAŠÍČEK, Z. \& SKUPIEN, P. 2004. Historie geologických a paleontologických výzkumů svrchnojurských a spodnokřídových sedimentů na Štramberku. [The Štramberk fossil site (Uppermost Jurassic/Lower Cretaceous, Outer Western Carpathians) - Two centuries of the geological and paleontological research.] Sborník vědeckých prací Vysoké školy báňské v Ostravě, R̆ada hornicko-geologická 50, 83-100.

VAŠIČEK, Z. \& SKUPIEN, P. 2005. Doplňky k historii geologických a paleontologických výzkumů na Štramberku. [Supplements to history of geological and paleontological research of Štramberk territory.] Sborník vědeckých prací Vysoké školy báňské v Ostravě, Řada hornicko-geologická 51, 1-6.

Vía BoAdA, L. 1981. Les Crustacés Décapodes du Cénomanien de Navarra (Espagne): premiers resultats de l'étude des Galatheidae. Geobios 14, 247-251. DOI 10.1016/S0016-6995(81)80008-3

Vía Boada, 1. 1982. Les Galatheidae du Cénomanien de Navarra (Espagne). Annales de Paléontologie 68(2), 107-131.

Waugh, D.A., Feldmann, R.M. \& Schweitzer, C.E. 2009. Systematic evaluation of raninid cuticle microstructure. Bulletin of the Mizunami Fossil Museum 35, 15-41.

Wehner, G. 1988. Über die Prosoponiden (Crustacea, Decapoda) des Jura. 154 pp. Dissertation zur Erlangung des Doktorgrades der Fakultät für Geowissenschaften der Ludwig-Maximilians-Universität zu München.

Wienberg Rasmussen, H., Jakobsen, S.L. \& Collins, J.S.H. 2008. Raninidae infested by parasitic Isopoda (Epicaridea). Bulletin of the Mizunami Fossil Museum 34, 31-49.

WierzBowsKi, H. 2004. Belemnite rostra: palaeoenvironmental implications for Late Jurassic seas. Palaeogeography, Palaeoclimatology, Palaeoecology 203, 153-168.

DOI 10.1016/S0031-0182(03)00673-4

Wright, C.W. \& Collins, J.S.H. 1972. British Cretaceous crabs. Palaeontolographical Society Monographs 126(533), 1-113. 